Para citar este artículo / To cite this article:

CASAS RIGALL, Juan (2022), "Las obras del famoso poeta Juan de Mena en el contexto filológico del Brocense: edición vulgata, exégesis y poética», Revista de Cancioneros Impresos y Manuscritos, 11, pp. 55-112. https://doi.org/10.14198/ rcim.2022.11.02

\title{
LAS OBRAS DEL FAMOSO POETA JUAN DE MENA EN EL CONTEXTO FILOLÓGICO DEL BROCENSE: EDICIÓN VULGATA, EXÉGESIS Y POÉTICA LAS OBRAS DEL FAMOSO POETA JUAN DE MENA IN THE LIGH OF EL BROCENSE'S PHILOLOGICAL PRAXIS: TEXTUS RECEPTUS, EXEGESIS, AND POETICS
}

\section{Juan Casas Rigall}

Universidade de Santiago de Compostela, Spain juan.casas@usc.es https://orcid.org/0000-0002-9530-508X

Este trabajo se enmarca en el proyecto de investigación El comentario filológico hispánico entre los siglos XV y XVII (PGC2018096550-B-100) del Ministerio de Ciencia, Innovación y Universidades, dirigido por Antonio Azaustre Galiana, y en el grupo de referencia competitiva GI-1377 de la Xunta de Galicia (GRC 2019-2022 / ED431C 2019/03), dirigido por Santiago Fernández Mosquera.

\section{RESUMEN}

Las obras del famoso poeta Juan de Mena brindan al lector de fines del Quinientos un corpus meniano remozado de acuerdo con el método filológico del Brocense. Para ponderar este trabajo, no basta su comparación con su edición previa de Garcilaso, pues los textos clásicos y neolatinos anotados por Sánchez contribuyen a perfilar aquella propuesta. A grandes rasgos, las ediciones comentadas del Brocense comparten una base común, si bien el grado de dificultad de la obra, su transmisión textual y el destinatario aportan matices decisivos. Como principio ecdótico fundamental, los textos de Sánchez parten de una vulgata, limada mediante enmiendas al margen del método propugnado por Poliziano. El comento sigue el patrón de anotación selectiva imperante desde finales del s. XV, y por lo general se dirige al escolar en formación, no tanto al erudito. Las anotaciones se ocupan principalmente de la exégesis explanatoria del texto y sus fuentes, con menor atención a la crítica textual y un escaso análisis poético. 
PALABRAS CLAVE: El Brocense; Juan de Mena; Hernán Núñez; crítica textual; comentario filológico

\section{ABSTRACT}

Las obras del famoso poeta Juan de Mena offered late-fifteenth-century readers a collection of Juan de Mena's works brought up-to-date through the application of El Brocense's philological method. In order to appreciate El Brocense's edition and commentary to Juan de Mena, a comparison with Garcilaso's previous edition of Mena's works is not enough. We get a more complete picture by considering El Brocense's other annotations to both Classical and neo-Latin texts. In general, the editions for which El Brocense provided a commentary have something fundamental in common, even if a commented text's difficulty, transmission, and intended audience complicated $\mathrm{El}$ Brocense's commentary process, Sánchez de las Brozas' editions and commentary are based on a textus receptus or vulgata, and are accompanied by marginal emendations, according to the method advocated by Poliziano. El Brocense's commentary follows the late-fifteenth-century standard of selective annotation, and usually is addressed to students rather than scholars. The glosses are mostly explanatory exegesis of the text and sources; less attention is paid to textual criticism; and poetic analysis is rare.

KEYWORDS: El Brocense; Juan de Mena; Hernán Núñez; textual criticism; philological commentary 
La aproximación a las ediciones anotadas que Francisco Sánchez de las Brozas dedicó a los dos grandes auctores castellanos de los siglos XV y XVI, Mena y Garcilaso, suele encararse como objeto autónomo, de modo que ambas obras se estudian ya en sí mismas, ya comparadas. Como ampliación del cotejo, normalmente se consideran también el comentario previo del Laberinto a cargo de Hernán Núñez y las anotaciones posteriores a la poesía de Garcilaso por Fernando de Herrera. Es natural, pues el análisis de la técnica editora y comentarística del Brocense quedará mejor aquilatada mediante trabajos de semejante tenor, propios y ajenos; y, en tal circunstancia, los comentos contemporáneos de Mena y Garcilaso deben ser los referentes básicos. ${ }^{1}$

Referentes básicos, sin duda, pero no exclusivos, porque el Brocense, como editor y comentarista, antes y después se ocuparía sobre todo de obras latinas y neolatinas, provechosos términos de comparación complementaria. Según la secuencia de las primeras estampas, la atención inicial de Sánchez se dirigió a autores modernos: Poliziano, Silvae (Salamanca, Andrea de Portonariis, 1554) y Alciato, Emblemata (Lyon, Rouillé, 1573). El primer clásico que edita, aunque sin comentario, es Pomponio Mela (Salamanca, Juan Perier, 1574), pero en su última etapa, después de las ediciones vernáculas de Garcilaso (Salamanca, Pedro Lasso, 1574, con reediciones en diversas imprentas, revisadas $\left[1577^{2}\right.$ y $\left.1589^{4}\right]$ o no $\left[1581^{3}\right.$ y $\left.1600^{5}\right]$ ) y Mena (Salamanca, Lucas de Junta, 1582), Sánchez se centrará en los poetas latinos -Virgilio, Bucolica (Salamanca, Diego Cusio, 1591), Ovidio, Ibis, y Ausonio, Gryphus (Salamanca, Juan Fernández, 1596) y Persio, Satirae (Salamanca, Diego Cusio, 1599)-.2 Y si en estos

1 Desde esta perspectiva se complementan los estudios comparados de los comentarios de Núñez y el Brocense a Mena por Jiménez Calvente (2002) y Casas (2016a) o, dentro la producción de Sánchez, el cotejo de sus ediciones de Mena y Garcilaso a cargo de Kohut (1975) y Morros (2003).

2 Para un panorama de los comentarios latinos del Brocense, véase Merino 1992: 267-302. Aunque aprovecharemos la doctrina de otros dos trabajos de Sánchez, se excluyen de este estricto catálogo sus comentos del Ars poetica de Horacio - en De auctoribus interpretandis (1558) e In Artem poeticam Horatii annotationes (1591) -, en donde interesa más la poética que la poesía en sí y, según veremos, responden a otros modelos teóricos. Asimismo, se considera solo en segundo plano la versión glosada del Enchiridion de Epicteto (1600), pues, como romanceamiento, sus anotaciones se ciñen a la materia, de donde el predominio de glosas morales. 
trabajos, aun con sus particularidades, no se advierte un enfoque esencialmente diverso de antiguos y modernos, lo mismo cabe decir respecto de latinos y romances, cuyos textos se establecen y explanan mediante la misma técnica filológica. Por ello, en un primer nivel, al ponderar cualquier edición del Brocense, sea de autor clásico o moderno, latino o vernáculo, cumple ampliar la perspectiva y considerar el conjunto de su comentarística, así como sus escritos sobre retórica y gramática, en donde también recurrió a los auctores. ${ }^{3}$ Un paso más allá, conviene asimismo otear siquiera el contexto paneuropeo de la edición humanística, algunas de cuyas líneas sigue Sánchez, en detrimento de otras. Esta es la idea que anima la presente exposición en torno al Mena del Brocense.

Las obras del famoso poeta Juan de Mena, nuevamente corregidas y declaradas por el maestro Francisco Sánchez, catedrático de prima de retórica en la Universidad de Salamanca salieron a luz en 1582 en el taller salmantino de Lucas de Junta, un volumen de $8+148$ hojas en doceavo (Ruiz Fidalgo 1994, no 1074). ${ }^{4}$ Tras el cuadernillo preliminar - con el prólogo «Al lector» y la serie usual de poemas encomiásticos-, la colección presenta como primera y principal obra el Laberinto comentado (ff. 1-98v), con su secuela de veinticuatro coplas («Como el adormido con la pesada», ff. 99$103^{r}$ ), apócrifa para Sánchez. Además, el volumen incluye la Coronación (ff. 104-120r), con anotaciones de parquedad progresiva; y después, solo con algún breve apunte ocasional, el Claro escuro (ff. 120 $-123^{r}$ ), una antología de "Otras suyas» ("Ya el hijo muy claro de Hiperión», Sobre un macho que compró de un arcipreste, "Amor, yo nunca pensé», "Santa paz, santo misterio» y los enigmas «Dezidme cuál es la cosa» y «¿Qué es el cuerpo sin sentido?», ff. 123-130》) y, como colofón, las inacabadas Coplas contra los siete pecados mortales (ff. 131-148').

3 En esta línea, en su estudio de los comentarios del Brocense y Herrera a Garcilaso, Codoñer (1986) atendió al marco general de las ediciones anotadas de Sánchez. Por su parte, al analizar el Garcilaso del Brocense, Ruiz Pérez (1988) tiene en cuenta los escritos del humanista sobre retórica y poética.

4 Manejo el ejemplar de la Biblioteca Nacional (U/11436), por donde cito, pero tengo en cuenta la edición de Gómez Moreno \& Jiménez Calvente (1994). Aquí y en todas las citas de textos de los siglos XV y XVI introduzco leves retoques ortográficos sin incidencia fonológica, y puntuación y acentuación modernas. 
No hay constancia de que esta colección meniana del Brocense conociese otra estampa coetánea, por más que modernamente se reitere la remisión a un presunto impreso complutense de 1586, a todas luces edición fantasma, y por partida doble, en una curiosa especie bibliográfica. ${ }^{5}$ De modo excepcional, Kerkhof (1995: 78) advertía en parte esta circunstancia a raíz del dato sospechoso de Vasvari (1976: 70), al conjeturar que el impreso de 1586 sería si acaso una estampa de Juan de Villanueva y Pedro de Robles, reedición de su Laberinto con glosa de Núñez de 1566, y no la obra de Sánchez. Pero, por añadidura, de acuerdo con Martín Abad (1991: 1479), este supuesto impreso alcalaíno de 1586 es ya una edición fantasma, fruto de una ficha equivocada de Simón Díaz (1965, no 4267). El catálogo de Ruiz Fidalgo (1994) confirma el error en cadena: tras 1582 tampoco consta en Salamanca ninguna otra edición quinientista del Mena anotado por el Brocense.

En la estampa de 1582, por el orden de presentación y el volumen de notas, el Laberinto es la obra de interés primordial para Sánchez y sus primeros lectores, según manifiesta ya el soneto preliminar de Bernardo de Guimera, que elogia al Brocense precisamente por desvelar el «Poema oscuro» (v. 7), antonomasia de las Trezientas. En carta a Juan Vázquez del Mármol de 9 de septiembre de 1579, el Brocense declaraba tener listas ya por entonces las anotaciones del Laberinto y la Coronación (Gallardo 1889, col. 452); y es fácil deducir por qué esta prelación: son estos los poemas menianos que mejor traslucen el legado clásico de autor. De otra epístola al mismo corresponsal a 15 de enero de 1581 se deduce que la iniciativa de incorporar otros poemas de Mena al conjunto, obvio reclamo comercial de la edición, no fue exclusiva del Brocense: «Paréceme bien que se impriman todas sus obras, como v. md. dice. Yo escrebí al cabo d'ellas [las ediciones de Laberinto y Coronación] que se viesen

5 Repiten el dato erróneo, por ejemplo, Gómez Moreno \& Jiménez Calvente (1994: xxxix), Morros (2003: 347) y, sin ir más lejos, Casas (2016a: 442). En realidad, tras 1582, las siguientes ediciones conocidas de Las obras del famoso poeta Juan de Mena se estampan en el tomo final de Opera omnia del Brocense al cuidado de Mayans $(1766,4)$ y más tarde en el impreso exento de Madrid, Repullés, 1804. 
todas allá, por si acaso se imprimiesen las demás» (Gallardo 1889, col. 457). Pero la innovación era solo relativa, porque la suma de una antología meniana al Laberinto la había iniciado ya Jorge Coci (Zaragoza, 1506), y culminaría en las respectivas ediciones de Juan Steelsio y Martín Nucio (ambas en Amberes, 1552), y de Villanueva y Robles con emisiones para Alonso Gómez y Miguel Rodríguez (Alcalá, 1566) (Brocato 2012; Weiss \& Cortijo 2015: 1001-1014).

De hecho, con respecto al corpus establecido por las estampas amberinas, la edición del Brocense solo incorpora dos breves composiciones, los susodichos enigmas, ambos de atribución dudosa, pues previamente circulaban como anónimos, uno desde el Cancionero General de 1511 y otro en pliegos sueltos (Pérez Priego 1979: 230 y 232; De Nigris 1988: 411 y 415). Si la tentativa de reunir las poesías de Mena fue colegiada, acaso estas dos adiciones no sean responsabilidad plena del Brocense. Con todo, otras ediciones de Sánchez se caracterizaron por incorporar alguna novedad al corpus del autor de turno. Así, en su Alciato se había añadido al corpus más inmediato un emblema sin imagen (Merino \& Ureña 2004: 94). En esta línea, más destacable son sus ediciones de Garcilaso. En su primera estampa de 1574, tras los preliminares, el encabezamiento del cuadernillo B incluía varios avisos de novedad, el último justamente la ampliación del corpus del toledano: «Obras del excelente poeta Garci Lasso de la Vega, de nuevo corregidas y emendadas por un original de mano muy antiguo, y añadidas algunas obras nuevas que nunca se han impresso». Como es sabido, el Brocense suma aquí seis sonetos y cinco poemas cancioneriles hasta entonces inéditos, y en la edición de 1577 incorporará tres sonetos y un villancico más. En contraste, ningún paratexto de la colección de Mena advierte al lector de las novedades del corpus, sea por su modesto empaque, sea porque ni siquiera se vería segura la paternidad de aquellos dos poemillas. Por ello, el título de 1582 se ciñe a lo más valioso de la nueva edición de las obras de Mena, nuevamente corregidas y declaradas por el maestro Francisco Sánchez, lo cual implica la lima de los textos y su anotación, aunque este segundo proceso se circunscriba al Laberinto y la Coronación, en consonancia con el plan inicial. 


\section{LA EDICIÓN VULGATA COMO TEXTO BASE}

Por innecesario, el Brocense no declara de manera expresa lo evidente: que su texto del Laberinto se basa en el monumento de Hernán Núñez, en concreto en su segunda versión, de 1505, repetidamente impresa hasta 1566, que actualizaba la redacción de 1499. Es difícil establecer qué estampas del Laberinto glosado por el Comendador Griego maneja Sánchez en particular, y lo mismo cabe decir sobre su modelo para la restante producción meniana, pero el cotejo de su texto con las invariantes de la glosa de Núñez basta para ilustrar el proceso de la versión vulgata como texto base.

Tal uso es común en las ediciones humanísticas europeas de los siglos XV y XVI, incluso después de las censuras de Poliziano y su escuela. Según ha subrayado Kenney (1974: $18-19$ y 25-26), con el advenimiento de la imprenta, el proceso más habitual supone que la nueva edición se basa en la edición precedente, constituida en vulgata, de modo que el stemma suele trazar una única línea vertical. En la tradición impresa del Laberinto, el texto de Núñez ya atestiguaba esta génesis: el origen remoto se halla en la princeps (Salamanca, c. 1486), seguida por las estampas de Zaragoza (1489) y Sevilla (1496), esta última modelo directo de la primera edición del Comendador (Casas 2020: 25-29).

Pese a sus notorias carencias, el método editor basado en la vulgata mostraba también ciertas ventajas, unas de raíz material -era más sencillo preparar el original sobre un ejemplar impreso con enmiendas manuscritas, lo que también simplificaba el proceso tipográfico - y otras de carácter académico: dentro de la comunidad erudita, la sucesión lineal de ediciones permitía evaluar la cadena de propuestas en igualdad de condiciones, con idénticos instrumentos ecdóticos, y sopesar cada nueva hipótesis con el referente de los eslabones anteriores.

Al discutir algunas glosas de Núñez, el Brocense está reconociendo su modelo, circunstancia que no requiere mayor subrayado por acomodarse al procedimiento habitual. El propio Comendador había adoptado como base el texto de Sevilla, 1496 
sin necesidad de manifestarlo. Y otro tanto haría el Brocense en su edición de las Silvas de Poliziano, aunque en este caso su texto base aún no haya sido identificado (Merino 1996); ${ }^{6}$ con los Emblemata de Alciato, que se fundan en una de las estampas costeadas por Rouillé en 1550 y 1551, el mismo editor de su comento (Merino \& Ureña 2004: 93-94); o con la poesía de Garcilaso, cuyo texto, por más que acoja conjeturas y lecturas traídas de otros testigos, parte de la edición salmantina de 1569, primera con el texto de Garcilaso exento, o su inmediata derivación madrileña de 1570 (Rosso 1990: 12-16).

Asimismo, la adopción de un texto previo como base permite explicar en buena medida la oscilante ubicación de las enmiendas propuestas, que solo ocasionalmente se incorporan al nuevo texto crítico, pues muy a menudo permanecen en las notas sin alteración del modelo. Esto, antes que indicar un diverso grado de seguridad en las hipótesis del editor, deriva de una práctica antigua - el comentario exento, sin la obra de referencia al lado-, a partir de la que, mediante un proceso lento, gradual y titubeante, las enmiendas van pasando desde el comento a los márgenes del texto, y de estos al texto en sí. Sin ir más lejos, en las dos versiones de la edición del Laberinto a cargo de Núñez se advertía este movimiento pendular (Casas 2020: 31-38).

El caso del Brocense no difiere. De una parte, a veces consigna sus enmiendas en el texto. Así, por vez primera en la tradición del Laberinto, Sánchez incorpora la más brillante conjetura de Núñez - la convincente reordenación de las coplas 245246 , invertidas en todos los testigos previos, que los editores modernos acatan desde Foulché-Delbosc (1904) - , enmienda que el Comendador solo había ofrecido en su glosa al arbitrio de los lectores: «D’esto juzgará el discreto lector como le ploguiere. Baste a mí haver demostrado el error» (Weiss \& Cortijo 2015: 879). Sánchez, persuadido por completo, no anota esta corrección, pero, aun sin reconocer la deuda con Núñez,

6 La colación es compleja, porque, aun suponiendo que se conserve la edición de Poliziano manejada por el Brocense, constan alrededor de una treintena de estampas europeas de las Silvas anteriores a 1554, una de ellas la edición complutense de Arnao Guillén de Brocar, c. 1515 (Coroleu 2014: 101-111 y 125-126). 
tampoco reclama para sí el mérito de secuenciar las estrofas del texto en consonancia, pues el Comendador había obrado oportunamente según la convención editorial de la época.

En otras ocasiones, la enmienda es original del Brocense, y por eso lleva subrayado anotador. Por ejemplo, la copla 215 del Laberinto, en torno a dos alusiones perifrásticas oscuras, da pie a sendas conjeturas:?

215e E vimos la gloria del bravo romano

del bueno

de Manlio

215hi aquel que con todas sus fuerças acorre

y aquel

contra la fambre del nuevo tirano
PN7 et passim

Princeps Núñez

Brocense

Núñez et passim

Brocense

La temprana glosa del Laberinto recogida en PN7 y otros manuscritos cuatrocentistas afrontaba ya la identificación de estos personajes, respectivamente como Marco Manlio (bravo romano) y Julio César (nuevo tirano), un vínculo anacrónico (Casas 2016b: 66-67 y 275-277). Núñez, en cambio, vio aquí a Manlio y su oponente Breno, el caudillo galo que atacó el Capitolio, lectura aceptada por los editores modernos. En contraste, la conjetura del Brocense, inspirada en Tito Livio, por una parte explicita el nombre de Manlio y, por otra, al alterar la sintaxis del v. 215h, no considera aquí una aposición referida a este mismo personaje, sino la alusión a otro defensor del Capitolio, Camilo, socorro de Manlio:

Y vimos la gloria del bueno romano. Ansí se lee en todos, y ansí leyó el Comendador; yo emendé de Manlio, y abaxo emendé y aquel que -antes se leía aquel que-. Mis emiendas tocan dos historias: la una de Manlio Capitolino y la otra de Camilo. Cuenta Tito Livio, libro 1, Dec. 5, que, estando los franceses sobre el Capitolio, haviéndose apoderado de la ciudad de Roma, Manlio le defendía muy bien; mas al fin, como no

7 Las variantes manuscritas e incunables del Laberinto pueden cotejarse desde Kerkhof (1995). Para la primera versión de Núñez (1499), sigo el ejemplar de la Biblioteca Nacional (Inc/651), y para la segunda (1505) el texto de Weiss \& Cortijo (2015). 
se pudiessen conservar, hizieron partido con Breno, capitán de los franceses, que darían mil libras de oro por salir en paz; y estando pesando el oro, faltaba un poco al peso, y juró el tribuno que ni tenían más oro ni dónde lo haver; entonces Breno puso la espada en la otra balança y dixo que si no cumplían todo aquel peso, que no estava hecho nada. Estando en esto, sobrevino Camilo dictador, que venía a ayudar a los del Capitolio, y dio sobre los franceses y desbaratolos, y restituyó la ciudad de Roma.

Ninguna de estas enmiendas de Sánchez resulta necesaria ni oportuna a la luz de la unánime tradición textual del Laberinto. ${ }^{8}$

Sin embargo, más común será que el Brocense se limite a proponer su enmienda en el escolio sin alterar el texto proporcionado por las Trezientas con glosa de Núñez:
$4 a$
¿Cómo que creo que fuessen menores?
Núñez ${ }^{1505}$ Brocense ${ }^{\text {texto }}$
Como no creo que fuessen menores
Núñez ${ }^{1499}$ Brocense $^{\text {nota }}$
Yo leería ansí: Como no creo que fuessen menores, y suspéndese la sentencia hasta passar a la media copla...
$75 \mathrm{~g}$ goza de cama tan rica de hermanos fama

$$
\begin{aligned}
& \text { Núñez }^{1505} \text { Brocense }^{\text {texto }} \\
& \text { Núñez }^{1499} \text { Brocense }
\end{aligned}
$$
Goza de cama. Parece que se havía de leer fama.

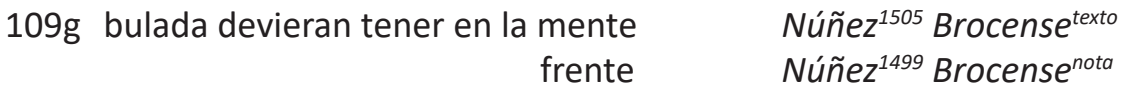
... y hase de leer frente y no mente, según se puede entender de la copla 56: «Que havía en la frente cada cual escrita / el nombre y la suerte por donde passava», y en la copla 57: «con túrbido velo su mote cubría».

Aunque en estos casos las enmiendas de Sánchez respecto del Laberinto de 1505 eran ya lecciones del Comendador en 1499, es improbable que el Brocense haya manejado precisamente esta edición. ${ }^{9}$ Dado que la segunda versión del comentario de Núñez

8 Véanse otros ejemplos de correcciones con anotación incorporadas al texto en 191d (Gortino) y 226b (estando tranquila).

9 Gracias a la correspondencia entre el Brocense y Vázquez del Mármol en la primavera de 1580, es bien conocida la anécdota del despiste de Sánchez al ignorar la vita de Mena de la primera edición del Laberinto de Núñez, suprimida por el Comendador en 1505, como Vázquez del Mármol le echa en cara y el Brocense reconoce con rubor (Gallardo 1889, col. 454). Pero, pese a su propósito declarado de tenerla en cuenta para enriquecer los magros detalles sobre la biografía del poeta en su edición, Sánchez no llegó a hacerlo, lo cual siembra serias dudas acerca de su uso directo del Laberinto de 1499. 
conoció al menos catorce impresiones antes de 1582, no es fácil determinar las fuentes directas del Brocense, aunque sin duda manejó más de una estampa; y si además consideramos los demás poemas de su antología meniana, la edición antuerpiense de Steelsio (1552) es buena candidata a texto base o, en puridad, a uno de ellos. Como fuere, la tradición de la princeps del Laberinto aportaba todas las variantes anteriores, que son por tanto dudosas enmiendas ope ingenii de Sánchez. Pero lo que cumple recalcar ahora es el uso fluctuante del editor, que puede incorporar o no sus correcciones al texto crítico. Nada extraordinario por entonces, según se ha dicho, debido al peso que aún se otorgaba a la vulgata. ${ }^{10}$

La justificación última de este modelo editorial radica en la confianza del filólogo en su ingenium, competencia que lo habilita para detectar errores y corregirlos sin ampararse en la tradición manuscrita e impresa, que, de ser contemplada, se hojea de manera asistemática. Es este el concepto característico del temprano humanismo, manifiesto aún en el tránsito del s. XV al s. XVI en la obra de Filippo Beroaldo, preceptor de Núñez; y esto pese a que se habían alzado ya las voces discrepantes de Poliziano y Barbaro, cuyos métodos, frente al hábito conjetural, propugnaban el respeto por las lecturas atestiguadas. La temprana muerte de ambos filólogos refrenó la nueva propuesta, pero, entrado el s. XVI, Piero Vettori recogería la antorcha de Poliziano para formar un equipo de trabajo en su estela, del que forma parte el aragonés Antonio Agustín.

En contraste con el método preferido por el Brocense, a este modelo editorial deudor de Poliziano alude con finura Asensio (1981: 53) mediante la perífrasis «en tiempos más cautelosos», la época en que, sin embargo, Sánchez continúa entregado al ingenium. El caso no es excepcional, pues el humanismo francés seguiría abanderando la cultura del ingenio; en este contexto destaca José Justo Escalígero, quien, después de aplicar el método de Poliziano en su edición de Catulo, regresa al modelo en donde

10 Otras enmiendas solo en nota pueden verse en $4 \mathrm{f}$ (a mucha costa), 8e (las siete Pleyadas), 130b (Tianeo) y 273 (Egica-Cinda-Ervigio). 
la intuición filológica del editor prevalece sobre la lectura conservada (Grafton 1983). En el caso de Escalígero, con todo, este viaje de ida y vuelta se fundaba en un profundo análisis del sistema de Poliziano. Sin alcanzar tal grado de conocimiento práctico, es plausible que el Brocense no se abandonase a la «furia conjetural» - de nuevo en términos de Asensio- en un mero acto anacrónico, sino como resultado de un planteamiento meditado.

Por el tiempo, entre las obras de Poliziano que alumbró la imprenta, la centuria prima de la Miscellanea (1489) permitía abstraer sus principios editoriales: de esta colección de notas filológicas a los clásicos latinos, especialmente dedicadas a la crítica textual, se deriva la necesidad de basarse en testigos conservados, reunidos, identificados y cotejados para establecer su genealogía, que revelará el testimonio más autorizado, a decir de Poliziano un manuscrito antiguo, en ningún caso la edición vulgata. El Brocense conoce bien la Miscellanea, pues la frecuenta en su comentario de las Silvas de Poliziano como documento del usus scribendi del autor y de su proceso de imitatio animado por el diálogo con los clásicos (Merino 1996: 426-428). De este modo, si Sánchez se desentiende del método genealógico de Poliziano, no se debe a desconocimiento pleno, sino a un postulado teórico distinto: la misma ratio que, para el Brocense, debe presidir la reflexión gramatical como garante del usus lingüístico puro también guiará la fijación del texto incluso por encima de los testimonios conservados. En el dominio ecdótico, por tanto, el método racionalista de Sánchez sanciona el ingenium del editor, cuya competencia lo exime de una recensión exhaustiva de la tradición textual y legitima así la adopción de una vulgata como base, pues, por defectuosa que esta sea, podrá ser corregida conjeturalmente.

\section{TIPOLOGÍA DEL COMENTARIO}

La anotación del Laberinto por el Brocense se amolda a un patrón ya centenario, pujante entre los humanistas desde las últimas décadas del s. XV: el comentario selectivo de los principales problemas exegéticos, poéticos y textuales de la obra 
analizada. En contraste, la glosa de Núñez, tanto en su edición de 1499 como en la revisión de 1505, representaba aún la modalidad del exhaustivo comento verso a verso que, inspirado de lejos en la explanatio a la manera de Servio, ofrecía por entonces sus últimas muestras notables de mano de eruditos eminentes pero tradicionales como el antedicho Beroaldo. El nuevo rumbo del comentario, cuyos príncipes son Poliziano y Barbaro, se impondría ya en los demás trabajos de Núñez — sobre Séneca, Plinio o Mela - y, según cabía esperar, en toda la producción comentarística del Brocense, desde las Silvas de Poliziano a las Sátiras de Persio.

En la esfera de comentarios cuyo denominador común es la anotación sobria, el enfoque académico oscila entre dos polos, desde la minucia filológica que el erudito ofrece a sus sesudos colegas hasta la explanación escolar concebida para alumnos y lectores diletantes. Al primer dominio pertenece la Miscellanea de Poliziano, en tanto que, por caso, las ediciones anotadas de Nebrija se orientan hacia el segundo, al igual que el Mena del Brocense y la mayoría de sus comentos, según iremos constatando.

Al considerar la actitud del Sánchez hacia el Comendador Griego y su anotación del Laberinto, recuérdese que el principio de la edición vulgata como texto base alcanzaba también el nivel de la glosa, y la comentarística anterior se tenía por bien mostrenco entre los humanistas, que aprovechaban sin reparo el trabajo ajeno. El proceso fue ya corriente en la Antigüedad. De hecho, el comentario «serviano» de Virgilio en realidad consta de varias capas de anotación, que Servio refunde con sus propios apuntes en la redacción que conocemos, de manos varias y difícil deslinde. Amparándose en Plinio -en cuya Naturalis historia renunció expresamente a declarar sus auctores a cada paso, porque, al asimilar su doctrina, la había hecho suya-, Poliziano actuará a la par en su Miscellanea, en donde, por ejemplo, nunca cita a Beroaldo pese a haberse servido de sus ediciones comentadas. Por su carácter monográfico, más llamativo aún es que las Castigationes Plinianae (1492-1493) de Barbaro silencien por completo las Adnotationes de Beroaldo a la Naturalis historia impresas 1476. 
Las obras de Juan de Mena aportan asimismo el caso de la Coronación, para cuyas anotaciones el Brocense se sirve de los comentos originales del poeta, pese a haberlos tachado de "boberías». ${ }^{11}$ Este proceso es palpable desde la primera copla de la composición, más que oscura, incomprensible sin la farragosa pero auxiliadora glosa meniana. En general, Sánchez, mucho más sobrio, elimina de raíz la triple exégesis de mitos (ficción, historia y moralidad) y abrevia de modo sobresaliente las declaraciones mitológicas, históricas y geográficas, pero su interpretación de pasajes concretos es deudora del autocomentario de Mena. El Brocense lo reconoce abiertamente en una ocasión: en el verso "que no la tardança d'ella» (18j), "esta voz d'ella se refiere a la sombra, según explica el mismo poeta en su glosa». Otras veces la remisión es menos explícita, como cuando Sánchez aclara la antonomasia vossiana de Séneca en el sentido figurado de 'suicida' de la copla 12: "Antojose al poeta que era nombre compuesto de se y neco, como si dixera 'hombre matador de sí mismo', y ansí dize que, porque los pecadores son homicidas de sí mismos, que todos estos ya comentados, cuanto al nombre, se podrían llamar Séneca». El uso de Mena, que el Brocense censura mediante el verbo antojar, lo explanaba el cordobés en la correspondiente glosa pseudoetimológica, que origina la referencia cuasiexpresa de Sánchez. Pero en otras ocasiones el Brocense asume el comentario sin dejar traza de la apropiación. De este modo, cuando el comentarista explica sucintamente el uso antonomástico de Alpes (v. 29c) por 'monte alto' («Alpes propiamente son los montes que apartan la Francia de Italia, mas aquí tómanse por cualquiera altura, como es el monte Parnaso»), está abreviando esta otra nota meniana:

Fasta los alpes de suso. Alpes dize aquí por 'altos montes', aunque propiamente Alpes montes de Galia son, de los cuales Virgilio dixo aerias Alpes, e diziendo aerias

11 «Solo en una cosa no podré venir en la opinión de aquel señor amigo de v. md.: en poner toda la glosa de Juan de Mena [a la Coronación], porque, allende de ser muy prolija, tiene malísimo romance y no pocas boberías (que ansí se han de llamar): más valdría que nunca pareciesen en el mundo, porque parece imposible que tan buenas coplas fuesen hechas por tan avieso entendimiento» (Carta a Vázquez del Mármol, a 20 de mayo de 1580; Gallardo 1889, col. 454). 
apartó palabra una de otra, ca los gálicos a cualquier monte alto alpe lo llaman; e por eso dixe aquí alpes, según lo testifica Isidoro en el décimo de las Etimologías, título nono «De montibus». La cual altura es comparada a la sabiduría, a la cual prudencia e sabiduría, cuando los hombres a ella vienen, estonce recrean y descansan, porque por ella saben conocer la perfección de la perdurable vida e el engaño de aquesta (Kerkhof 2009: 86).

De aquí el Brocense elimina la moralización y el envío a Isidoro (Etym. 14, 8, 18), de quien procede el comentario gramatical sobre Virgilio (Georg. 3, 474), muy confuso en Mena. ${ }^{12} \mathrm{Y}$ aunque Sánchez aprovecha lo esencial para la elucidación del sentido, la propia refundición justifica la falta de referencia expresa al comentario modelo.

En tal línea, el Brocense maneja y cita el Laberinto de Núñez en los márgenes esperables. De entrada, resultaría ilusoria la pretensión de acallar un trabajo precursor repetidamente impreso entre 1499 y 1566, no solo en España, y obra de un célebre catedrático de su universidad. Según el hábito, a partir de lo obvio -Sánchez basa su texto y su glosa en el texto y la glosa de Núñez-, no es extraño que el nuevo comentarista se abstenga de subrayar a cada paso que la mayor parte de sus anotaciones son resumen más o menos actualizado de las notas de su predecesor. En el siguiente escalón, corregir el comentario previo es una de las estrategias más comunes de las ediciones humanísticas, que informa buena parte de la producción del Sánchez (Merino 1992: 278-279). Por ello, es de todo punto natural que el Brocense cite expresamente a Núñez sobre todo para enmendarle la plana, y solo le reconozca la pertinencia de alguna propuesta ocasional. ${ }^{13}$

No es el Laberinto un caso aislado, pues, en su edición del De situ orbis de Pomponio Mela (1574, con reedición en 1598), Sánchez se valía de otro trabajo del

12 Isidoro considera en aeries Alpes una suerte de epíteto, pues aeries 'aéreos' apuesto a Alpes 'montes elevados' redunda en una nota inherente al sustantivo: «... et dicendo aerias verbum expressit a verbo, nam Gallorum lingua alpes 'montes alti' vocatur» (Etym. 14, 8, 18; Oroz \& Marcos 1982-1983). Pero la versión de Mena («e diziendo aerias apartó palabra una de otra...») oscurece el sentido genuino.

13 Por ejemplo, a propósito de la lectura corrupta en la tradición impresa que sin no querer (Laberinto $112 \mathrm{fg})$, el Brocense señala la oportuna enmienda de Núñez, que si no querer. 
Comendador, las Castigationes a Mela (1543), si bien con actitud algo diferente. De acuerdo con la estampa de 1598, aunque esta edición del Brocense presenta el texto crítico de Mela desnudo de anotación, el prólogo a Manuel Sarmiento apunta detalles de interés. Tras declarar su evidente deuda con Barbaro, autor de otras célebres Castigationes in Pomponium Melam (1493), y con Núñez, el Brocense extracta y comenta sus nuevas enmiendas más notables, "paucas, sed insignes» (Mayans 1766, 2: 520). ${ }^{14}$ En estas líneas, el nombre de Barbaro no reaparece ya, según el signo de los tiempos, pero sí Núñez, invocado incluso como maestro en las aulas salmantinas (Mayans 1766, 2: 522). En algún caso, la referencia se hace en términos marcadamente elogiosos; así, en el segundo capítulo del libro III, a propósito de la enmienda Atlas dense consurgens frente a la habitual lección deturpada satis de se consurgens, Sánchez loa el mérito del Comendador: "hunc locum foelicissime, ut multa alia, Pincianus emendavit». En otra ocasión, la conjetura de Núñez se refrenda con un lugar concordante, lo que pondera el ingenium del Pinciano y la erudición de Sánchez: «Lib. III, c. 7. Olim Notissima India: Pinciano displicebat vox notissima, \& dixit mihi \& aliis discipulis scribendum novissima. Ego postea, ex commentariis Graecis in Dionys. De situ orbis, elegantissime locum correxi». Y alguna vez es natural que aflore la discrepancia, aquí amparada en nuevos paralelos de los auctores y la paleografía: «Ibid. Olim: Inter ipsa ostia rara tenet regio. Pincianus dicebat minus male posse legi rara viret regio. Ego, ex ductu literarum \& ex omnibus cosmographis, substitui Patalene regio».

Es verdad que, en conjunto, en estas notas del Brocense el elogio de Núñez domina sobre la réplica, en contraste con la anotación del Laberinto. Pero es clara la causa: las Castigationes de Núñez a Mela no se acompañaban del texto de la obra, justo al contrario que el trabajo de Sánchez, un texto sin notas, por lo cual se complementaban sin entrar en competencia. Con el poema de Mena ocurría lo contrario, y el Brocense debía marcar distancias. Aunque sumar otras composiciones

14 En las ediciones comentadas latinas y neolatinas del Brocense sigo los textos de Mayans (1766), con excepción de los Bucolica de Virgilio, en que uso la edición de Mañas Viniegra (2014). 
al Laberinto era una buena estrategia, el meollo y el reclamo editorial seguían estando en las Trezientas, de ahí que Sánchez, sin contravenir el hábito dominante en Europa, se muestre aquí más cicatero con los logros de Núñez. En general, de acuerdo con el panorama trazado por Hinojo (2003: 34), esta es la actitud dominante en los comentarios del Brocense a los clásicos: se apoya en comentos previos, pero los cita expresamente sobre todo para contradecirlos, y más si se trata de autoridades como Valla o Poliziano.

En lo tocante al sustrato filológico, la teoría y la práctica del comentario de texto en Sánchez demuestra la convivencia de dos modelos fundamentales: la exercitatio o análisis retórico integral frente a las annotationes explanatorias autónomas.

En De auctoribus interpretandis (1558), el Brocense propone tres objetivos básicos en la exercitatio comentarística, de raíz oratoria: los dos primeros, la quaestio o tema y los argumenta y loci, atañen a la inventio, y el tercero es la dispositio, teoría ilustrada mediante el análisis del Ars poetica de Horacio en un híbrido de paráfrasis y comento. Sin embargo, ninguna de sus ediciones de clásicos y modernos se amoldará a este patrón. En su etapa de madurez, Sánchez volvería al texto horaciano con unas In Artem poeticam Horatii annotationes (1591), en donde reduce al mínimo la doctrina preliminar, pero amplía el comentario del poema. En este nuevo análisis, el Brocense traza un esquema mejor perfilado: divide la composición horaciana en secciones, cada una introducida por un epígrafe que determina su quaestio, y a continuación presenta el texto del capítulo con marginalia sobre fuentes y paralelos, seguido de una paráfrasis y, aparte, unas annotationes finales que aclaran el sentido y la forma, con principal atención a la teoría literaria. ${ }^{15}$

Pero respecto de este último modelo, exceptuado el caso de las Satirae de Persio, las restantes ediciones anotadas del Brocense solo comparten las annotationes declaradoras. La causa del planteamiento diverso depende en gran medida del

15 Sobre la interrelación del De auctoribus interpretandis y las Annotationes al Ars poetica, véase los trabajos de Merino (1992: 256-267 y 284-297; y 1994a) y de López-Cañete (1999). 
destinatario de la mayor parte de estos trabajos, no tanto el estudioso cuanto el estudiante, a quien se ofrecen textos inteligibles merced a anotaciones selectas y sobrias, aunque incluso aquí, como iremos comprobando, hay grados. En tal ámbito escolar, del prólogo de la edición de las Silvas de Poliziano (1554) se desprende un programa ideal de anotación tripartito (exégesis, poética y crítica textual), que, según ha puesto de relieve Merino (1996), solo responde en parte a la realidad de este mismo trabajo. En la práctica, el comentario contempla principalmente el nivel exegético, con atención especial a las fuentes de Poliziano y las concomitancias con otros autores, y un recurso habitual a la paráfrasis de pasajes difíciles, pues el móvil básico del Brocense es establecer el sentido de los versos. Las notas de crítica textual son escasas, de donde se desprende que su texto base le resultó satisfactorio. Menor desarrollo alcanzan aún las glosas de poética, cuyo intento sería demostrar la riqueza expresiva de los poemas, porque, según el prejuicio vigente desde la Antigüedad, esta se da por supuesta.

En conjunto, aunque cada edición impondrá los matices de un perfil propio, este modelo anotador trimembre subyace a la principal producción comentarística de Sánchez.

\section{EXÉGESIS Y FUENTES}

La tarea básica del Brocense es explanar el sentido del texto desde el punto de vista lingüístico y conceptual. En el primer estrato emplea dos estrategias complementarias: la paráfrasis de pasajes especialmente oscuros y la nota gramatical sobre voces insólitas y construcciones difíciles, centrada en la etimología y la sintaxis. En un segundo dominio, el objetivo es la elucidación de alusiones mitológicas, referencias históricas y geográficas, y diversos realia. En uno y otro nivel, las fuentes inmediatas del autor o, en un sentido más amplio, los paralelismos con obras anteriores y posteriores son la base de las explicaciones. Según comprobaremos, las fontes aducidas pueden estar asimismo al servicio de la anotación poética o, más a 
menudo, crítico-textual, por lo cual se constituyen en pilares del comento y agentes de unidad entre los diferentes planos de análisis.

De este modo, en el subconjunto de comentarios dedicados a moderni se considera inexcusable la identificación de los modelos del autor, que en las notas a la silva Nutricia de Poliziano o los Emblemata de Alciato propicia simultáneamente la interpretación de pasajes, la ponderación de la cultura clásica del artífice y el alarde erudito del comentarista. En este ámbito, el comento de Garcilaso luce particularidades inherentes a la lengua romance contemporánea, que no requiere la anotación de tipo léxico y gramatical, aunque se mantenga la paráfrasis de versos aislados; la explanación de las alusiones mitológicas e históricas persiste, pero la rica localización de las fuentes de Garcilaso se constituye en un fin en sí mismo, en donde con frecuencia los modelos invocados no buscan tanto la declaración de un pasaje cuanto afirmar el proceso de imitatio como guía de la creación poética.

En cuanto a los comentarios de clásicos, la doble dimensión de anotaciones lingüísticas y conceptuales conserva su carta de naturaleza, con los correspondientes escolios gramaticales, mitológicos, históricos y de realia como principales fundamentos. Si el comento de los Bucolica es un trabajo por encargo, la selección personal de dos poemas tan complejos como el Ibis de Ovidio y el Gryphus de Ausonio demuestra el arrojo didáctico de Sánchez, empeñado en hacerlos accesibles al lector escolar. El Ibis es una invectiva de oscuro destinatario y erudición enciclopédica, en particular mitológica; en cuanto al Gryphus, supone un ejercicio retórico y numerológico basado en la simbología del tres, en donde se han querido ver raíces gnósticas y neoplatónicas. En ambos casos, el Brocense se ciñe al sentido literal de los versos. En excepcional contraste, en su última edición comentada, las Sátiras de Persio, Sánchez se aproxima al modelo aplicado al Ars poetica horaciana: no divide los poemas con epígrafes de sección, pero recurre a la ecphrasis o paráfrasis -ahora más ceñida al texto, sin intromisiones anotadoras, según ha mostrado Merino (1992: 292-297)—, seguida de unos magros escolios en donde descuella la identificación de adagios. 
A grandes rasgos, si en el comentario intertextual de los modernos dominan las fuentes estrictas sobre las más vagas concomitancias de motivos y formas en una tradición literaria común, cabría suponer que con los clásicos se volviesen las tornas. No obstante, el Brocense tampoco renuncia a señalar fuentes precisas, con lo que su planteamiento no varía demasiado. Así, por ejemplo, a decir de Sánchez, el v. 46 de la Égloga IV de Virgilio presenta ecos de Catulo, en tanto que el v. 24 se ilustra mediante analogías con Eusebio o Sannazaro (Mañas Viniegra 2014: 61-62 y 67-68). En cuanto al asunto central de la Sátira II de Persio, sobre las necias peticiones a la divinidad, entronca con el Segundo Alcibíades, diálogo tradicionalmente atribuido a Platón que el Brocense considera modelo principal (Mayans 1766, 2: 306). En uno y otro ámbito, pues, se mantiene el principio de análisis comparado a la manera de Poliziano, cuyo método genealógico trascendía lo puramente ecdótico para alcanzar la exégesis intertextual con remisión a fuentes y otros paralelos. Lógicamente, tanto el género y el estilo de la obra tratada como, en su caso, las glosas previas condicionan cada nuevo comentario del Brocense. Con todo, el carácter selectivo de sus anotaciones criba aquellos materiales, proceso en donde afloran sus intereses.

Según lo visto, es comprensible la prioridad que Sánchez confiere al Laberinto y la Coronación en la obra de Mena, cuyo elemento grecolatino es el acicate, en contraste con la poesía amorosa, satírica y religioso-moral, que se edita sin comento. El tratamiento de Garcilaso fue análogo: sus poemas cancioneriles no se escolian -salvo en cierto modo "Pues este nombre perdí», sobre el suicidio de Dido, que porta una rúbrica en función de nota: "Traduciendo cuatro versos de Ovidio», en referencia a Heroidas 7, 193-196 (Sánchez 1574, f. 84v) -; y análogo silencio afecta a los sonetos XXI, XXV y XXVIII, y la canción III, en donde la perspectiva panegírica y personal excluye o atenúa las alusiones clásicas y, así, la oportunidad de comento erudito.

Centrados en el Laberinto, los principales estratos susceptibles de glosa son el mapamundi, los círculos de los planetas y los atributos de cada astro manifiestos en una panoplia de figuras ejemplares del pasado y el presente, con sus casos y fortunas. 
De resultas, geografía, astronomía y astrología, mitología, las historias antigua, cristiana y moderna, y los realia son la materia dominante en las notas. Además, en el dominio gramatical y estilístico, el cultismo, el arcaísmo y el neologismo menianos constituyen otro vivero de apuntes. Una pretensión análoga explica que el comentario de Núñez, que operaba verso a verso, fuese un mamotreto. El Brocense, aun siendo muy selectivo, sigue estas líneas maestras, con particular atención a mitología, historia y geografía; en el dominio gramatical, el léxico y la etimología están, además, condicionados por una realidad cronológica, el casi siglo y medio que separa a Mena y Sánchez, con el escalón intermedio de Núñez.

Para fundamentar sus anotaciones, en la senda del comentario humanístico de su tiempo, el Comendador había basado buena parte de su estrategia en la propuesta de fuentes - en especial, el De imago mundi atribuido a Anselmo y la Farsalia de Lucano, y en menor medida la Eneida- y, en un sentido más lato, mediante paralelismos grecolatinos (Homero, Platón, Aristóteles, Cicerón, Estacio, Estrabón, Juvenal, Livio, Ovidio, Plinio, Séneca, Quintiliano, Suetonio, Valerio Máximo, Diodoro Sículo, Gelio, Plutarco, Mela, Donato, Servio...), cristianos (Agustín, Eusebio y Jerónimo, Alberto Magno, Isidoro, Bernardo, Gregorio, Tomás de Aquino...) y modernos (Petrarca, Boccaccio, Bruni, Biondo, Valla, Tortelli o Poliziano). Sánchez aprovecha este ingente acervo de referencias, tan rico como desproporcionado, pero lo reforma considerablemente: suprime decenas de glosas, resume siempre el discurso, elimina las citas literales e intenta estratificar la acumulación de auctores discriminando lo esencial de lo accesorio. De otra parte, si ha lugar, añade fuentes y paralelos con moderación.

Algunos ejemplos. La copla 34 del Laberinto de Mena abre el mapamundi del poema, que da ocasión a multitud de alusiones cosmográficas y geográficas. Las anotaciones de Núñez comienzan con un desmañado catálogo de autoridades -Avieno, Dionisio Líbico, Mela y Plinio-, que se corta de forma abrupta («Otras algunas auctoridades podría traer...») antes de la pertinente identificación del modelo 
principal: "Y deve saber el lector que en toda esta cosmographía Juan de Mena imita y sigue a sancto Anselmo en un libro que compuso De imagine mundi, tanto que casi en cosa ninguna no se aparta d'él». A partir de aquí, el Comendador ilustra punto por punto los tecnicismos del poeta: el espérico centro (34a) y las cinco zonas de la tierra con sus correspondientes círculos celestes (septentrional, solsticial, equinoccial, brumal y austral, 34b). La siguiente estrofa, en donde Mena se aplicaba a la descripción de Asia la Mayor, da pie a una digresión de Núñez sobre los tres continentes. En contraste, las notas del Brocense son mucho más precisas, y no escatiman el pullazo implícito al Comendador. Por lo que respecta a la copla 34, Sánchez se limita a caracterizar escuetamente espérico centro («dize por la tierra, que es centro de la esfera, que es el cielo»), a tachar de trasnochada la teoría de las cinco zonas («Cinco zonas ponían los antiguos, las cuales ya no son menester porque eran imaginaciones, digo cuanto al calor y frialdad») y a definir con brevedad bruma, solsticio y equinoccial, con una coda en censura de la erudición improcedente: «Todos estos son términos de esfera, que no sirve de nada tratarlos aquí a la larga, pues tienen proprio lugar». Aquí el Brocense calla lo consabido: que él mismo acaba de publicar una Sphaera mundi (Salamanca, Ildefonso de Terrananova, 1579) sobre estas materias. Pero, acerca de la copla 35, vuelve a la carga: "Tengo por muy impertinente cosa mostrar en este lugar qué sea cosmographía y geografía, porque el que aquí lo leyere no ha de salir geógrapho. Ya presuponemos que sabe esto de los libros donde se enseña ex professo, y ansí lo presupone Juan de Mena». Como colofón, Sánchez aprovecha como propio un argumento de Núñez, con el que pretende apuntalar su refutación: "Solamente advierto que nuestro poeta no sigue en esta descripción de las tierras a Pomponio ni a Plinio ni a Ptolomeo, sino casi al pie de la letra traslada a san Anselmo en un libro que compuso De imagine mundi».

La mitología es otro de los campos propicios para esta clase de reconvenciones. En la primera semiestrofa de la copla 103 del Laberinto, dentro del círculo de Venus, Mena evocaba perifrásticamente el mito de Tereo, Procne y Filomela, que Núñez 
desgrana en todos sus pormenores, con remisión final a las Metamorfosis: «Esta fábula cuenta más largamente Ovidio en el sexto libro de Metamorfóseos». Obsérvese la ambigüedad del Comendador: ¿se propone aquí el pasaje ovidiano como fuente directa de Mena o como mero paralelismo? En velada respuesta, el Brocense despacha la cuestión en un par de líneas: «La fábula de Tereo, Progne y Philomela es muy vulgar. Cuéntala muy a la larga Ovidio, libro 6 Metam.»; y es indudable este carácter trillado, pues el mismo Mena se recreaba en el truculento relato en una extensa autoglosa de la Coronación (7f). De nuevo, se aprovecha la aportación esencial del Comendador, la remisión a las Metamorfosis, pero se denuesta la prolijidad en el tratamiento de elementos accesorios y, dada la vulgaridad del mito, se pone en cuestión que Mena esté siguiendo específicamente a Ovidio.

La aducción de fuentes y analogías del Laberinto es, en efecto, afán del Brocense, cuyo puntal inexcusable es Núñez, con frecuencia tácita más que expresamente censurado por su tendencia al acarreo. Otra cosa es que la crítica de Sánchez sea justa. Así, con relación a la copla 164 del poema - sobre los malos augurios que se ciernen sobre la escuadra del conde de Niebla-, Núñez citaba principal y abundantemente a Lucano y Ovidio como referentes, y en menor medida a Virgilio, seguido de una nutrida nómina que incluye a Plinio, Claudiano, Suetonio, Aristóteles, Alberto Magno, Séneca, Josefo, Capitolino y Eutropio. En cambio, el Brocense zanja el caso mediante la única fuente que considera apropiada, oscurecida en el comentario del Pinciano por la maraña de autoridades:

Lucano, en el fin del libro, pone estas y otras señales, desde el verso que comiença "Prodigiis terras implerunt»; y aunque hay otros muchos autores donde hay semejantes señales escritas -como es Ovidio, al fin del libro decimoquinto Metamorpho. - , basta citar a Lucano, porque nuestro poeta siempre le sigue cuando se le ofrecen semejantes imitaciones.

Se advierte bien la irritación ante el cúmulo erudito del Comendador, a menudo tan forzado que reclama el proceso expeditivo de Sánchez. Ahora bien, de acuerdo con 
Lida (1950: 64-67), aunque Lucano constituya aquí el fundamento de Mena, este ha recurrido a Virgilio y Ovidio para detalles complementarios, por lo que grosso modo resulta atinada la imitación compuesta de modelos confluentes que se desprende de la glosa de Núñez. El justo medio se encuentra entre la red intertextual desatada del Comendador y el parco antídoto del Brocense, comprensible pero por momentos un tanto romo.

A continuación, en las coplas 169-172 del Laberinto, el conde de Niebla refuta los agüeros funestos de su piloto, basándose en la ausencia de otras señales de tempestad. En su línea habitual, el Comendador remite principalmente a Plinio, Virgilio y Lucano, pero adereza su argumentación mediante Claudiano, Vegecio, Avieno, Cicerón, Séneca, Isidoro, Ovidio, Servio, Alberto Magno, Aristóteles y Gelio. El Brocense se aplica de nuevo a la selección. En cuanto a la estrofa 169, «las señales de tempestad pone muy a la larga Plinio, capítulo último del lib. 18, y Virgilio en el tercero de las Geórgicas, a quien aquí sigue Juan de Mena, y Lucano en el quinto, hablando de Amyclas marinero». Si bien estas fuentes coinciden con la propuesta de Núñez, el Brocense apunta a las Geórgicas como modelo principal, como respecto de la copla 170 («Todo esto es de Virgilio en el dicho lugar»). A raíz de la alusión meniana a los alciones y el semilunio o tiempo del alción (Laberinto 171), Sánchez reemplaza todos los auctores invocados por Núñez -Alberto Magno, Aristóteles, Plinio e incluso Virgilio- por un paralelismo moderno, los Emblemata de Alciato y su propia edición anotada («D’este [semilunio] dixe largamente en los comentarios de los Emblemas de Alciato»). Acerca de la estrofa 172, «todo es de Virgilio en el dicho lib. 3, y algo está aquí de Lucano", sin necesidad de recurrir a los Cicerón, Avieno e Isidoro del Comendador. En este caso, a decir de Lida (1950: 67), en efecto, las fuentes fundamentales de Mena se encuentran en «el libro I de las Geórgicas y en el pasaje derivado de la Farsalia V, v. 540 y sigs.», por lo que las sobrias anotaciones del Brocense resultan ahora muy justas. 
Según el prólogo «Al lector» de su edición de Mena, uno de los móviles y justificantes de Sánchez es facilitar la lectura: "Yo espero que, leyéndose agora este poeta con más claridad y menos pesadumbre que antes, será mi trabajo bien recibido» (p. 9). Por lo general, de primeras cabría imputar esta falta de claridad y sobra de pesadez a las dificultades inherentes a la alta poesía del Cuatrocientos y su transmisión textual, con el Laberinto a la cabeza. Sin embargo, como ya notó Bell (1925: 99), el Brocense insinúa que tales obstáculos derivan más bien de la edición de las Trezientas farragosamente glosadas por el Comendador, o del enfadoso autocomentario meniano de la Coronación. En este sentido, según han señalado Weiss \& Cortijo (2015: 4749 y 114), ya las estampas del Laberinto de Núñez patrocinadas por Nucio y Steelsio aligeraban la anotación original, y la segunda incluso añadía un índice para gobernarse en aquel piélago, la imponente glosa que hacia 1580, de acuerdo con el testimonio de Miguel Sánchez de Lima, se consideraba más oscura que el texto mismo de Mena. ${ }^{16}$ Por ese tiempo, el tamiz del Brocense culmina el proceso. En cuanto a la Coronación, en el s. XVI siguió imprimiéndose con la propia glosa del poeta, que allanaba la interpretación de muchos pasajes, pero añadía el lastre de su concepción medieval de la exégesis y el fárrago, inasumibles para Sánchez, quien se negó a mantener en su edición un cúmulo que a su juicio deslucía los apreciables versos de Mena. Fuera de estos dos poemas mayores, es verdad, las demás composiciones de la antología del Brocense carecen de anotación en sentido estricto, por lo cual - pensemos ante todo en el Claro escuro o "Ya el hijo muy claro de Hiperión», que circulaban muy deturpados desde la segunda década del Quinientos - la mayor «claridad y menos pesadumbre» de su edición aquí dependerá en exclusiva de un texto depurado.

16 «Y que Juan de Mena - aunque no se os ha acordado d'él, siendo uno de los que más celebrados han sido en España, como dixo Hierónymo Arbolante en las Abidas y en una sátira que en el principio d'ellas hay contra todos los poetas-, que hizo coplas que se han de leer a descansadas, porque, como tenía preñada vena, trezientas d'ellas nos dexó preñadas. Y si no, miradlo en la glosa del Comendador Griego que para declaración del texto hizo, que tiene necessidad de comento para que se pueda entender y, según que a muchos parece, está más escura que el mismo texto» (Sánchez de Lima 1580, f. $\left.13^{\text {rv }}\right)$. 
En el caso particular del Laberinto, las abundantísimas fuentes, citas y referencias acumuladas por Núñez demandan, por tanto, la reescritura sobria y mejor discriminada de mano del Brocense. Pero aquel mismo volumen dificultaba la novedad en la propuesta de modelos y paralelismos. Sánchez, sin embargo, no desperdicia los escasos resquicios que encuentra para complementar este capítulo del Pinciano.

En algún caso, la nota del Brocense apunta una analogía más que una fuente directa, como en el breve escolio sobre Calíope y las demás Musas en la copla 3 del Laberinto: "Nueve musas cuentan los poetas, cuyos nombres y oficios se leen en una epigrama que anda al fin de las obras de Virgilio. Calíope es la que tiene a cargo los poemas heroicos, y por esso la invoca aquí el poeta». Sánchez remite al poema mnemotécnico "Clio gesta canens, transactis tempora reddit», obra tardoantigua que transmite el Mitógrafo Vaticano I/ (Suppl. R 14a; Kulcsár 1987) y por lo general se atribuía a Ausonio o Virgilio - al Mantuano, por ejemplo, aún en la tercera parte del Teatro de los dioses de la gentilidad (1689), continuación del tratado de Baltasar de Vitoria por Juan Bautista Aguilar-. En el «epigrama» en cuestión se asocia sucintamente cada Musa a un género literario o una actividad especulativa y artística, de donde la oportunidad didáctica de la referencia.

Más adelante, a propósito de la «cándida púrpura» de la reina María de Castilla (Laberinto 72a), una anotación léxica de Sánchez pretende corregir al Comendador con fundamento en pasajes de Horacio y Virgilio, si bien el Brocense se muestra excesivamente puntilloso con la glosa de Núñez, no desdeñable. Según el Pinciano, la voz púrpura no vale aquí por 'hábito real carmesí', sino por 'hábito real', lo que habilita la aposición del calificativo cándida 'blanca': Núñez sugiere una ampliación metonímica del sentido de púrpura en el uso de Mena, que puede describir así una vestidura regia de color blanco. Este proceso semántico, implícito en la argumentación, es obviado por el Brocense, que descarta cándida púrpura como ligadura ilógica: «El Comendador dize que no entendamos aquí púrpura por 'carmesí', sino por 'vestidura y hábito real', cuyo insigne era púrpura, pero no se suelta por ahí la duda, pues dize cándida. Si hay 
'púrpura blanca', no hay cuestión». Como alternativa, Sánchez se acoge al adjetivo purpureus en el sentido de 'hermoso', bajo la autoridad de Horacio y Virgilio: «Pero yo hallo en latín purpureus por 'cosa hermosa': Horacio en la primera oda del cuarto dixo "purpureis oloribus" [v. 10] hablando de los cisnes; y Virgilio, "purpureos spargam flores" [Aen. 6, 884] y "lumine vestit / purpureo" [Aen 6, 640-1], y en otras muchas partes». La acepción de purpureus 'hermoso' está, en efecto, bien documentada, y ya Porfirio explicaba el verso horaciano de este modo (Commentum in Horati Carmina $4,1,10)$, aunque el primer ejemplo de la Eneida es un tanto dudoso. ${ }^{17}$ Por esta vía, el Brocense entiende cándida púrpura como 'color blanco hermoso' o 'blanca hermosura', pues no precisa cuál de los adjetivos considera sustantivado. En líneas generales, los editores modernos oscilan entre las interpretaciones de Núñez y Sánchez, si bien es posible sumar una tercera lectura: mantener púrpura como 'carmesí' y tomar cándida por 'hermosa, deslumbrante', como en la expresión virgiliana candida Dido (Aen. 5, 571), acepción no menos documentada que purpureus 'hermoso'. En cualquier caso, la hipótesis del Brocense es convincente, como también la propuesta de Núñez, descartada por aquel con excesiva rotundidad.

En el verso inicial la copla 86 del Laberinto, el primer consejero eximio de la serie meniana es el más prudente de los griegos, tan solo nombrado: «Néstor el antiguo se nos demostró». Esta mera mención da pie a una amplia nota de Núñez sobre la genealogía de Néstor y sus méritos, basada en Diodoro Sículo, Cicerón, Homero, Nevio, Dares y Ovidio. El Brocense sustituye toda esta falange de autoridades por una cita de Horacio: "Nestor componere lites / inter Peliden festinat et inter Atridem" [Epistulae 1, 2, 11-12]. Dize Horacio que Néstor tratava de componer a los reyes Achiles y Agamenón». De este modo, Sánchez reprueba sutilmente el modelo anotador del Pinciano mediante una referencia omitida por este, entre las decenas de alusiones clásicas a Néstor que cabría añadir.

17 Todas las referencias de los autores clásicos siguen PHI. Classical Latin Texts del Packard Humanities Institute (2021). 
En el reverso vicioso del sabio consejero se encuentra Pándaro, el arquero troyano que rompió la tregua durante el duelo de Paris y Menelao (Laberinto 88), sobre quien el Brocense aduce la evidentísima fuente última: «Cuenta Homero en el 2 de la llíada...». Pero la obviedad tiene un propósito claro: denostar la correspondiente glosa de Núñez, el cual, pese a admitir a Virgilio como modelo principal («d'él tomó esto aquí Juan de Mena, en el quinto de la Eneida»), antes ha dedicado a Pándaro una cumplida nota basada en la Ephemeris belli Troiani de Dictis, fabulosa crónica de un impostado contendiente en Troya, una mixtificación tardoantigua inasumible para los humanistas.

En el ya aludido lugar de los versos $112 \mathrm{fg}$ en donde se reconoce la oportuna enmienda del Comendador si no querer, el Brocense añade a vuelapluma una fuente pertinente no señalada por Núñez, las Epistulae ad Brutum $(6,1)$ de Cicerón, con cita incluida: «Cicer. Ad Brut.: "nihil minus videtur hominis quam non respondere in amore iis a quibus provoceris"». Una de cal y otra de arena, pues.

Es hecho extraordinario que el Comendador, en un pundonoroso comentario verso a verso, deje campo franco para la elucidación de fuentes, pero a la altura de las coplas 177-187 del Laberinto, en el relato de la muerte del conde de Niebla, Núñez se excusa: «Todo esto escrive el poeta tan claramente, hasta acabar la muerte del conde de Niebla, que no ha menester exposición alguna» (176a). Y poco después, en un contexto similar - el planto de la madre de Lorenzo d'Ávalos (204-206) -, el Pinciano deja otras tres estrofas sin anotación. La renuncia es ciertamente limitada a lo largo y ancho de trescientas coplas, y el Brocense intenta aprovechar la ocasión. Con respecto al primer pasaje, en la copla 186 del Laberinto, en el tono característico de sus anotaciones a Garcilaso, apunta Sánchez:

Si fe a mis versos es... Hermosa imitación de Virgilio, libr. 9 [446-449], sobre la muerte de Niso y Eurýalo: «Fortunati ambo! Si quid mea carmina possunt, / nulla dies unquam memori vos eximet aevo, / dum domus Aeneae Capitoli immobile saxum / accolet imperiumque pater Romanus habebit». 
Extrañamente Lida (1950: 64-75) elude el comentario del fragmento, pese a que el paralelismo postulado por el Brocense resulta plausible: como Virgilio al invocar en admiratio a los difuntos Niso y Euríalo («Fortunati ambo!», 9, 446), Mena se vale del apóstrofe exclamativo para redirigir el discurso al de Niebla («iOh ínclito conde...», 186b) y, al igual que el Mantuano («Si quid mea carmina possunt...»), condiciona a la fuerza de su poema la eterna memoria del sacrificado héroe ( $\mathrm{Si}$ fe a mis versos es atribuida...», 186e), en donde "Nulla dies umquam memori vos eximet aevo» (447) deriva en «jamás la tu fama, jamás la tu gloria / darán en los siglos eterna memoria» (186fg). ${ }^{18}$

Menos persuasiva parece a primera vista la propuesta sanchiana sobre la fuente del planto de la madre de Lorenzo d'Ávalos (Laberinto 205-206), anotación del Brocense asimismo inducida por el episodio de Niso y Euríalo: «Esta copla [205] y la siguiente es pulida imitación de Virgilio, cuando la madre de Eurýalo llora a su muerto hijo, lib. 9, Aeneid. [481-497]». En la obra de Mena, el lamento en sí consta de tres argumentos sucesivos: el apóstrofe de la madre al asesino de su hijo, a quien se habría ofrecido como víctima propiciatoria para la salvación del vástago (205bh); un argumentum a fictione: según el proceso natural, si ella hubiese muerto antes, sus hijos habrían podido ocuparse de cerrar sus ojos y honrarla (206ac); y la conclusión: al haber fallecido ya su hijo, ella morirá muchas veces, lavando las heridas fatales con tristes lágrimas que el difunto no podrá agradecerle (206dh). Pero el paralelismo con el planto de la Eneida es pálido: aquí la madre de Euríalo apostrofa a su hijo muerto, tachado de cruel por haber caído en tierra extraña sin que su madre pueda celebrar sus exequias (481-489); en Virgilio sigue una serie de preguntas retóricas al difunto en tono de reproche (490-492), y dos nuevos apóstrofes: a los rútulos, como enemigos de Euríalo, de quienes la madre implora la muerte (493-494), y a Júpiter, a quien igualmente suplica un piadoso morir (495-497). Como recuerda Lida (1950: 75-

18 Más abajo, en la copla 208, sobre la muerte de Fernando de Padilla, Mena recupera el motivo («Si fe merecieron mis versos trobando, / jamás en los siglos será muy perfecto / el nombre famoso...», 208eg) y el Brocense su anotación: «D’esto se trató en la copla 186». 
79), Menéndez Pelayo y Quintana, a todas luces inspirados por el Brocense, abundan en esta colación, frente a la que la estudiosa argentina presenta otras alternativas. Para empezar, Lida retrotrae el análisis a las coplas 203-204 del Laberinto, prólogo del planto en discurso directo, en donde aprecia en la actitud de la madre de D'Ávalos notas concordantes con otro pasaje de la Eneida, la reacción de Ana ante su hermana Dido moribunda (Aen. 4, 672-673 y 684-685): ambas plañideras se infligen lesiones de duelo y besan la boca del cuerpo exánime al tiempo que lavan sus heridas, este detalle ya en el planto del Laberinto (206f). Pero no todas las huellas virgilianas que Lida propone resultan definitivas. Así, en el lamento meniano, Lida (1950: 76-77) descubre rotunda la evocación de otro episodio de la Eneida (11, 149 y ss.), el llanto de Evandro por su hijo Palante: «La escena del Laberinto está evidentemente trazada a semejanza de este duelo y no del de Euríalo; y las quejas de la madre de Lorenzo Dávalos también están más cerca por el pensamiento de las quejas de Evandro que de las de la anciana del lib. IX». Con todo, la nueva analogía se limita a la inútil optación de ambos progenitores, que habrían preferido morir antes que sus hijos. En línea similar, Lida propone como fundamento complementario de Mena otros versos virgilianos de este mismo episodio, por las referencias a la Fortuna en boca de Eneas (vv. 4244) - que Lida considera base de la imprecación del Laberinto (202eh), otra vez de manera forzada, aunque su argumento está presidido por un quizá-, y por voz de Evandro, que fija el mérito y fortuna de Eneas en la venganza sobre Turno (vv. 179180) - ahora sin correspondencia con ningún verso del Laberinto, más allá del uso de la voz fortuna-. Pese a sus reticencias iniciales, Lida (1950: 78) reconoce al menos dos versos menianos traídos del planto de la madre de Euríalo: «ofende con dichos crueles al cielo» (203e) / «caelum dehinc questibus implet» (Aen. 9, 480) y «mataras a mí e dexaras a él» (205c) / «conicite, o Rutuli, me primam absumite ferro» (ibid., v. 494). En fin, como analogía de la muerte prematura del joven D’Ávalos, «que fizo en un día su fin e comienço» (Laberinto 201g), Lida propone el caso de Lauso, también caído en su primer combate (Aen. 10, 426 y ss.), aunque en un lapsus remite al v. 508 del mismo 
canto («haec te prima dies bello dedit, haec eadem aufert»), que en realidad se refiere a Palante; a decir de Lida (ibid., p. 79), aquí Mena parece más afecto a la emulación ovidiana «haec tibi prima dies, hace tibi summa fuit» (Her. 11, 114), «perteneciente al lamento de Cánace, el cual imita evidentemente al de la madre de Euríalo». Se cierra el círculo, pues, y volvemos a la anotación del Brocense, que debe ser complementada con el recurso a otras fuentes, pero no carece de tino. Porque Mena, que no compone aquí un planto cristiano, sino a la manera de los clásicos, imita el modelo virgiliano sin seguir de hilo un pasaje concreto, como advirtió Lida, mediante la emulación de las constantes del género con algún aderezo cuasi literal entreverado.

Fuera ya del estrecho margen que deja Núñez para glosas virginales, el Brocense vuelve a completar al Comendador en cuanto puede. Desde el punto de vista crítico-textual, resulta muy interesante la anotación de Sánchez a la copla 226. Pero, ceñidos ahora a la exégesis del fragmento, coincide grosso modo con la propuesta de Núñez, con adición de un par de pasajes horacianos. A propósito de la inestabilidad de la Fortuna con los poderosos, el Brocense evoca la oda 1, 35, con cita de los vv. 11-14: «... Te [sic] / purpurei metuunt tiranni / iniurioso ne pede proruas / stantem columnam», que añade autoridad poética a los erráticos referentes del Pinciano (Jerónimo, Sidonio Apolinar, Vopisco, Dión Prusense y Plutarco). Y de inmediato, a raíz de la alusión meniana al objetivo eminente de los rayos («e como los rayos las torres mayores / fieren enante que no en las baxuras»; 226ef), Sánchez recuerda otro pasaje de Horacio, este de la oda 2, 10 («feriunt summos / fulmina montes», vv. 11-12), que engrosa otra vez los paralelismos apreciados por el Comendador (Séneca, Ovidio y Quinto Curcio). Como en algún caso previo, el Brocense rehúsa la repetición de las referencias de Núñez, y marca músculo erudito con una quisquillosa adición.

Como hemos podido comprobar, al lado de fuentes en sentido estricto, el comentarista suele apuntar pasajes concordantes de autores anteriores, contemporáneos o posteriores a la obra glosada. En este lato dominio intertextual, con respecto a los antiguos aflora una cierta indefinición, pues las citas y referencias que 
ilustran un pasaje anotado a menudo se aducen sin precisión genealógica. Pero tanto Núñez como el Brocense y, en general, los comentadores de su época, al proponer una fuente sin ambages, tienden a aclararlo mediante fórmulas con imitar o seguir. En el caso de Sánchez, acabamos de examinar ejemplos en una y otra dirección: con fuentes directas, las anotaciones a las coplas 34-35 (Imago mundi), 164 (Lucano), 169-170 (Virgilio), 172 (Virgilio y Lucano), 186 y 208 (Virgilio) y 205-206 (Virgilio); y con paralelos, las glosas a 3 (pseudo Virgilio), 72 (Horacio y Virgilio), 86 (Horacio), 88 (Homero), 103 (Ovidio) y 226 (Horacio).

Entre las concomitancias ha aparecido asimismo Alciato, a cuyo emblema 178 [179] «Ex pace ubertas» remite Sánchez respecto de la alusión del Laberinto (171) a los alciones y sus hábitos, interpretados como señal de bonanza marítima en su glosa latina ("D'este dixe largamente en los comentarios de los Emblemas de Alciato»). Según se ha señalado, el Brocense demostraba su interés por la obra mucho antes de su edición comentada de 1573, pues ya en sus Silvas de Poliziano (1554) recurría a los Emblemata con cierta frecuencia (Merino 1996). Otras glosas del Laberinto testimonian tal querencia, de nuevo con remisión a su trabajo impreso en Lyon. De este modo, a propósito de chimerino 'quimérico' (Laberinto 242e), el Brocense envía al punto en que allí se ocupaba de la Quimera: «D’esta traté largamente en el comento de los Emblemas de Alciato». La imagen del emblema 14 figura a Belerofonte en lucha con el híbrido monstruoso, según Alciato representantes respectivos del buen consejo frente a la maldad polimorfa. Pero ahora la nota del Brocense, amparada bajo la etimología del neologismo meniano, funciona como mera adenda mitológica sobre la Quimera, sin relación esencial con los versos del Laberinto, que en este contexto enumeran las sustancias brujeriles en el antro de la maga de Valladolid. Recupera finalmente la pertinencia esta otra glosa. A raíz de la alusión de Mena al camaleón, «que del aire se cría» (Laberinto 259a), apunta el Brocense: «En el comento de las Emblemas de Alciato traté largo del camaleón, y cómo es falso pensar que no come y que se mantiene del aire, aunque puede no comer por algunos meses. El camaleón, 
porque muda colores, significa los aduladores e inconstantes». El comentario y el emblema 53 «In adulatores» se avienen al sentido del pasaje del Laberinto, en donde Mena denostaba a los nobles disidentes de Álvaro de Luna, pues el contexto de Alciato es la censura de la perfidia y la deslealtad.

Estos mismos emblemas de Alciato y su comentario por el Brocense de 1573 permiten ilustrar constantes y distingos respecto de las anotaciones al Laberinto. En general, los comentos de los Emblemata son más completos y sistemáticos. Aunque, en el conjunto de su producción, el Brocense tiende a emplear indistintamente los marbetes annotatio, scholium y commentarius, no parece casual que su edición de Alciato sea la única intitulada Commentaria, que en la terminología de Erasmo o Vives designaban el modelo de mayor calado (Merino 1992: 269-281; Ureña 2004). La aproximación de Sánchez consta aquí de dos secciones principales: una introducción general -sobre asunto, fuentes y sentido del mote de cada emblema, a veces con un sucinto análisis métrico liminar-, seguida de la anotación de versos selectos del epigrama declarador. Las fuentes son el elemento preferente, según advierte ya el prefacio («In quo mihi unus praecipue scopus fuit propositus: ut unde sumptum fit unumquodque emblema indicarem»; Mayans 1766, 3: 3-4). Por ejemplo, por lo que respecta al emblema 14, para Belerofonte y la Quimera el Brocense remite a Homero, Fulgencio, Píndaro, Erasmo, Hesíodo, Celio Rodígino, Plutarco y, sobre todo, una llias Latina escoliada, sin distinguir un modelo directo. En cambio, para el emblema 53, Sánchez propone como fuente inmediata el «De adulatore et amico» de los Moralia de Plutarco, y para el camaleón envía a Plinio, Aristóteles, Plutarco (Alcibíades), Ovidio y al proverbio «Chamaleonte mutabilior», recogido en los Adagia de Erasmo. En cuanto al emblema 179 (178), el Brocense vuelve a la vaga intertextualidad, con referencias a Aristóteles, Simónides, Virgilio y Servio, el adagio «Alcedonia sunt apud forum» — de nuevo en la colección erasmiana-, Plinio, Plutarco («De amore prolis» y «De sollertia animalium», de los Moralia), Basilio, Esopo, Luciano y Ovidio. 
En no ecuánime contraste, este mismo método le parece improcedente cuando el Comendador lo aplica al Laberinto. Las anotaciones de Sánchez, más sucintas, tienen un mismo cimiento en el comentario de Núñez, que el Brocense sintetiza o complementa sobriamente, procesos ambos que conducen a la parquedad: cuando resume o estratifica las fuentes aducidas por su precursor, Sánchez extrema la brevitas, por lo cual se abstiene de repetir los precedentes advertidos por aquel; y cuando añade algún modelo o correlato, lo hace con sumo laconismo. En el caso de la Coronación, la constricción era mayor, porque aquí el propio Mena revelaba sus fuentes y poco cabía sumar de sustancia. En este sentido, en la producción del Brocense el Alciato se alinea con las anotaciones a Garcilaso, trabajos ambos pioneros sin el condicionante de comentarios previos, en términos absolutos para el poeta toledano y en gran medida respecto del emblemista. ${ }^{19}$ Esta mayor libertad de Sánchez cristaliza en dos comentos cuya atención preponderante son las fuentes y las analogías, más detalladas porque cualquier aportación en este dominio resultaba novedosa.

Pero también hay una diferencia notable: las anotaciones garcilasianas son más parcas y carecen de la estructura sistemática del comentario de Alciato, por lo que aquellas se asemejan más en lo formal a las glosas al Laberinto. En esto entran en liza los diversos tipos de comentario que el Brocense cultiva, de objetivos delineados por sus destinatarios. Grosso modo, las ediciones salmantinas - así, las Silvas de Poliziano, los Bucolica de Virgilio o el Ibis de Ovidio- se dirigen al lector escolar, al estudiante universitario que vela sus primeras armas filológicas en el Colegio Trilingüe

19 Es verdad que, en su traducción de Alciato, Bernardino Daza (1549) se refiere a una obra suya previa, las Enarraciones Latinas sobre los Emblemata, de la cual no se conoce ejemplar, que no debió de alcanzar gran difusión (Talavera 1996: 682-683). Más interesante es el caso de Juan de Mal Lara, amigo del Brocense, que dejó inédito un comentario de los Emblemas parcialmente reconstruido (Selig 1990: 37-70). A decir de Merino (2004), Mal Lara y Sánchez empezarían a trabajar sobre Alciato simultáneamente, mediado el s. XVI, y con cierta comunicación personal, pues no todas sus coincidencias pueden explicarse convincentemente desde fuentes comunes. El comentario del Brocense, de hecho, alude a Mal Lara en términos elogiosos en diversos pasajes, de todo lo cual se desprende un grado de colaboración. 
o el studium salmantino bajo la tutela del Brocense. ${ }^{20}$ En cambio, con la edición de Alciato -como la Minerva o el Organum dialecticum et rhetoricum en sus respectivos dominios - se tiene en mente otro público: al tiempo que la obra alciatina establecía un nuevo género literario y editorial, los comentarios humanísticos de los Emblemata instauran un modelo paralelo, que mira a "la comunidad científica europea» (Talavera 1996: 683), al erudito antes que al lector curioso o estudiantil, de ahí el mayor esmero del comentarista, que ya no escribe para sus alumnos, sino para sus colegas, de donde la estampa en Lyon por Rouillé, referente internacional de los libros de emblemas. ${ }^{21}$

Las ediciones de Garcilaso y Mena pertenecen a la primera categoría: son trabajos escolares concebidos para el lector universitario o diletante, no comentos humanísticos, lo que justifica su parquedad y la falta de una estructura sistemática. Ciertamente, el volumen de apuntes sobre las fuentes y su variedad es superior en el Garcilaso, según ha subrayado Morros (2003), lo que en la práctica recalca la imitación compuesta de sus versos en contraste con el caso de Mena, para quien Sánchez suele proponer modelos únicos, de donde parece inferirse menor riqueza intertextual. No obstante, en esta discordancia actúa el condicionante susodicho: la anotación de Garcilaso, al carecer de precedentes, es magnífica oportunidad de lucimiento filológico por medio de los modelos aducidos, mientras que, para la Coronación y el Laberinto, las extensas glosas de Mena y el Comendador, a menudo sobre fuentes, aconsejaban una labor de síntesis cuya originalidad anotadora radica en la precisión. Por lo tanto, a la hipótesis de una evaluación imitativa diversa de Garcilaso y Mena por el Brocense debe incorporarse este factor de corrección.

20 Para la caracterización del comentario escolar del Brocense, véase Mañas Viniegra 1992 y 1993, Guarino 1996 e Hinojo 2003.

21 Aunque actualmente solo conservemos la edición lionesa del comento de Alciato por el Brocense, Mayans $(1766,1: 24)$ da noticia de otra estampa en Padua, no inverosímil, que reafirmaría la difusión europea de la obra. 


\section{RETÓRICA Y POÉTICA}

Incluso antes de 1573, año en que el Brocense obtendría la cátedra en Salamanca, las portadas de sus obras solían declarar su título de profesor de retórica, catedrático a partir de aquella fecha. Esta convención editorial resulta común por el tiempo, pues la categoría académica del autor es reclamo mercadotécnico, y esto al margen de que la materia de la obra sea estrictamente oratoria, ya que también se consideraba pertinente en el campo más dilatado de las letras. Así, en la portada de la estampa salmantina de la Minerva (1587), Sánchez es presentado como «primarius rhetorices». Y no es inconveniente arrimarse al hábito para justificar tal intitulación en las ediciones comentadas del Brocense, porque su contenido mismo poco ayuda: apenas aportan notas de retórica y poética, y, frente a los dominios exegético y textual, cuando estas afloran ni siquiera se advierte un patrón claro.

Bien es verdad que las ediciones de Sánchez prestan atención preliminar al género literario si el propio título de la obra invita a ello -así, la silva de Poliziano, el emblema de Alciato o la ecloga de Virgilio-, pero sus explicaciones, muy breves, son más etimológicas que genológicas. Igualmente, el Brocense puede determinar la quaestio o tema central, que en el caso de las Silvae o los Emblemata se especifica en cada composición, pero este dominio de la inventio no se completa con la atención a argumenta y loci en pasajes específicos de la obra (Merino 1992: 300-302). En el conjunto editorial del Brocense, las notas de carácter retórico y poético, sin ser abundantes, se concentran en la elocutio y están subordinadas a la declaración del texto.

En su edición de las Silvas de Poliziano, en efecto, este tipo de escolio se demuestra escaso y asistemático, normalmente ancilar de la intelección. Un análisis detenido revela solo sorpresas ocasionales. Por caso, en una de las adiciones de la segunda edición de la obra (1596), para explicar la construcción que abre el v. 17

de Nutricia, el Brocense recurre al concepto retórico de prosapodosis, esto es, la disgregación de elementos complementarios a lo largo de un enunciado, que exige 
determinar sus correlaciones para una correcta lectura - aquí las alusiones perifrásticas alternativas y recurrentes a Júpiter, Rómulo y Baco-. En realidad, para establecer tales correspondencias y aclarar el sentido de los versos habría bastado con desvelar las alusiones mitológicas, que Sánchez de hecho aclara, proceso en donde la idea de prosapodosis resulta prescindible. De este modo, se ha aprovechado la explanación del sentido para ilustrar un concepto retórico interesante de por sí. Pero estamos ante un uso aislado y tardío, ausente en la edición de 1554.

Concebidos en otras circunstancias, los comentarios de los Emblemata de Alciato prestan una atención algo mayor a estos elementos. Para empezar, en la introducción de ciertas glosas destacan observaciones sobre métrica, que obviamente no explanan el texto, sino que constituyen un fin en sí mismo. De este modo, en la tríada de ejemplos que examinábamos atrás, el comentario del emblema 53 comienza con uno de estos apuntes: «Primus quisque versus est hexameter; secundus quisque, iambicus dimeter, constans quatuor iambis, recepto tamen in locis imparibus spondeo» (Mayans 1766, 3: 136). Aun así, estas precisiones prosódicas aparecen en contadas ocasiones. ${ }^{22}$ Los escolios sobre poética y retórica tampoco abundan: solo se recurre al concepto oportuno cuando ello permite aclarar el sentido o justificar la gramática, móvil principal de las notas del Brocense. Por ejemplo, en el mentado emblema 178 [179], la expresión "Laetus erit Cereri, Baccho quoque fertilis annus» (v. 5) se explica como metonimia en donde las deidades Ceres y Baco designan la fecunda cosecha agrícola y vitivinícola de un año fértil, lo cual allana la interpretación. En contextos afines, Sánchez echa mano de tropos y figuras para esclarecer pasajes. ${ }^{23}$

22 Con noticia métrica introductoria, véanse además los emblemas 7, 9 y 108 [109]. De manera aún más aislada, la nota a un verso específico puede contener detalles prosódicos; así, sobre pariete al comienzo del epigrama del emblema 32, apunta Sánchez: «pes est proceleusmaticus, constans ex quatuor brevibus, sic $\cdots$, quales multi sunt apud Virgilium» (Mayans 1766, 3: 94). Véanse asimismo las notas a los emblemas 10, 60 y 143 [144] (Mayans 1766, 3: 37-38, 144 y 275).

23 Véanse ejemplos en los comentos de los emblemas 12 (perífrasis, v. 1), 42 (hipérbole, v. 2), 76 (epíteto, v. 5), 77 (alegoría, vv. 1-2), 78 (alegoría, v. 5), 102 [103] (perífrasis, v. 2), 120 [121] (prosopopeya), 137 [138] (alegoría) y 148 [149] (catacresis, v. 1) (Mayans 1766, 3: 41, 118, 169, 173, 209, 239,266 y 281). 
Capítulo aparte merecen los metaplasmos y las figuras de construcción, atinentes a morfología y sintaxis, que permiten asumir la ruptura de la norma gramatical mediante licencias poéticas; por esta vía, en el emblema 39 («Concordia») el Brocense señala la sinéresis con que debe escandirse la voz cöentibus (v. 3), en tanto que la construcción stellatus corpora del emblema 49 ( «In fraudulentos», v. 1) se explica como helenismo o antíptosis, en una muestra de acusativo griego. ${ }^{24} \mathrm{El}$ ornato poético, pues, interesa al servicio de la perspicuidad, no en cuanto objeto autónomo; por ello, cuando el Brocense aprecia alguna composición retóricamente destacable, se limita a una nota genérica - por caso, de la letra del emblema 161 [162] («Auxilium nunquam deficiens») apunta a bulto: «Est epigramma venustum et figuris abundans» (Mayans 1766, 3: 300)-. En conjunto, el mayor interés relativo que, así y todo, el comentario de Alciato demuestra hacia el elemento poético está indudablemente condicionado por el destinatario de la obra, que, según acabamos de ver, es más bien el lector erudito.

En las anotaciones a Garcilaso, en cambio, los apuntes sobre lengua y elocución poética brillan por su ausencia, laguna que aprovecharía Herrera para cimentar un enfoque novedoso que el Brocense consideró improcedente. ${ }^{25}$ Para Sánchez, la dificultad garcilasiana emana de ciertas alusiones mitológicas, ocasionales conceptos oscuros y no pocos errores textuales, pero no del léxico y la gramática, que por tanto no precisan explanación mediante licencias oratorias. Según asume el prólogo desde 1577, la evaluación poética de Garcilaso es intrínseca al proceso creador y crítico de la imitatio, que el mero registro de fuentes pone ya de relieve a cada paso, de ahí que

24 Otras anotaciones sobre metaplasmos y figuras de construcción se localizan en los emblemas 2 (enálage, v. 1), 32 (displasiasmus o geminación consonántica, v. 1), 90 [91] (apócope, v. 3), 143 [144] (sinéresis, v. 1) y 209 [210] (antífrasis) (Mayans 1766, 3: 14, 95, 190, 275 y 361).

25 Ya solo sobre el soneto I («Cuando me paro a contemplar mi estado»), mientras Sánchez se ciñe a un apunte intertextual desde Plutarco, Herrera comenta el numerus fundado en las vocales a y o, el zeugma de paro (vv. 1-2), la metáfora de pasos (vv. 2 y ss.), la apódosis desde el segundo cuarteto, la aporía de no sé (v. 6), la epanalepsis de sé (vv. 6-7), el políptoton en torno a acabar (vv. 8-10), la hipótesis o argumentum a fictione de si ella... (v. 11) y un argumento de mayor a menor (vv. 12-14) (Pepe \& Reyes 2001: 282-286). El Brocense, como ya notó Mayans (1766, 1: 38), se burlaría de este método anotador en el prólogo a la traducción de Os lusíadas de Camões por Luis Gómez de Tapia (Asensio 1984: 20). 
sea innecesario redundar en el análisis del ornato verbal. Tal concepción vincula el apunte intertextual con la crítica literaria, aunque esta no explicite los fundamentos elocutivos del poeta.

En fin, como última muestra, en las Adnotationes a los Bucolica de Virgilio hay un par de noticias retóricas que remiten a la Minerva, si bien el objetivo es distinto en cada caso. Para explicar la expresión Galatea reliquit 'Galatea me abandonó' (Égloga I, v. 30), el Brocense recurre al concepto de euphemismos, pues del contexto se desprende que en realidad Galatea fue abandonada por el pastor Títiro. Sánchez envía a la Minerva, cuyo libro IV trata del eufemismo con abundantes ilustraciones («Unius vocis unica est significatio»). A decir del comentarista, el discurso cobra sentido mediante una lectura eufemística, de manera que la nota retórica propicia la correcta interpretación. En otro pasaje, en contraste, la simple alusión virgiliana a las Parcas (Égloga IV, v. 47) es la excusa para remitir al capítulo «Exploditur grammaticorum antiphrasis» en el mismo libro de la Minerva, en donde, adaptando la tercera de sus Paradoxa, Sánchez censuraba las caducas etimologías medievales por antífrasis - como el «Parcas, quod nulli parcant» de Isidoro (Etym. 1, 37, 24), que se remonta a Servio-. Pero con esto no se está explicando el verso virgiliano, ahora forzado pretexto para la doctrina gramatical.

El comentario de Mena discurre de modo similar, con limitada atención al estilo. En el prólogo, al justificar la pertinencia de una nueva edición de Mena, el Brocense determina la idea presidente de su poesía: «la materia que trata es una philosophía moral y un dechado de la vida humana, ilustrada con diversos exemplos de historias antiguas y modernas, donde se halla doctrina, sabor y elegancia» (Sánchez 1582, f. *5r). Se advierte en esto un añejo concepto del accessus, la pars philosophiae, que, desde una óptica retórica, implica la quaestio o asunto nuclear de la obra (Casas 2016a). Y aunque se reclame principalmente la vigencia doctrinal de Mena - frente a la dudosa moralidad de algunos contemporáneos-, los conceptos de «sabor y elegancia» miran al estilo. A renglón seguido, el Brocense hace hincapié en este elemento: 
Dizen algunos que es poeta muy pesado y lleno de antiguallas, y dizen esto con tanta gravedad que, si no les creemos, parece que les hazemos injuria; y no advierten que una poesía heroica como esta para su gravedad tiene necessidad de usar de palabras y sentencias graves y antiguas para levantar el estilo (Sánchez 1582, f. * $5^{\text {rv }}$ ).

Defiende así el Brocense como decoroso un estilo adecuado al género, según el patrón de la rota Virgilii, ahora en contraste con la oscuridad injustificable de ciertos poetas amorosos de su tiempo. Por añadidura, Sánchez reivindica la perspectiva histórica en la evaluación de Mena, que no merece desprecio solo «porque en nuestra edad hayan salido otros de estilo muy diferente» $\left(1582\right.$, f. $\left.^{*} 6^{r}\right)$. No obstante, si bien es claro que con «exemplos de historias antiguas y modernas» y «poesía heroica» Sánchez se refiere en primera instancia al Laberinto, en sus anotaciones poco se desarrollará la fina crítica estilística aquí apuntada. Ya es revelador que la copla 119 del poema, sobre los grandes oradores, apenas si dé lugar a tres líneas del comentarista, con remisión a los Cánones cronológicos de Eusebio-Jerónimo, la identificación de Gabiano y una noticia histórica sobre Casio Severo. Esta parca glosa está en consonancia con las escasas notas sobre elementos retóricos y poéticos, pauta de las ediciones del Brocense, como apuntes subsidiarios del sentido y la puritas gramatical. Ahora incluso hay una novedad por defecto: la ausencia casi absoluta del metalenguaje técnico de rigor.

En este limitado comentario poético de los versos del Laberinto, impera la elocutio. Aquí el recurso a los metaplasmos, licencias del barbarismo, resulta ciertamente esperable para explicación del léxico de Mena, y tal ocurre en la nota sobre blasmar (7b), en donde por una vez nombra Sánchez el schema de base en la forma alterada: "Blasmar es 'maldezir', síncopa de blasfemar». Núñez, que no consideraba arcaica la voz, nada anotó al respecto, de ahí la oportunidad del Brocense. Pero, fuera de este ejemplo, cuando el uso meniano se basa en un metaplasmo, en el mejor de los casos Sánchez habla genéricamente de licencia o figura poética -así, «Lagos Metoes dixo por poética licencia, por dezir Meotes» (42f) y "usó aquí de una figura poética llamando Cindo a Cindosundo» (272b) - o incluso de corrupción inducida por el metro 
- «No se lea (...) Eurigo, sino Ervigio, aunque este por causa del verso se corrompió» (273d) - , pero no se precisan las modalidades, respectivamente metátesis, apócope y una suma de metátesis y síncopa. Fórmulas similares se apreciaban en las notas correlativas del Comendador - «por dar lugar al consonante» (42f) y «usó aquí de una figura poética» (272b) - , pero es de notar que el Brocense se contente con el mero resumen, sin aprovechar para introducir el tecnicismo apropiado. En otros lugares incluso falta el hiperónimo de licencia o figura en el apunte de Sánchez — «Cratón dixo por Crates» (118a), «Gabiano está por Gabino o Gallión» (119b), «No hay sibilla Dimeta, mas hay Demo» (121e) y "Phrygineta dixo por Phrygia» (121h) -, notas anticipadas por el Comendador con similar renuncia terminológica.

Mayor indefinición se advierte aún en el dominio de los tropos, por más que el Brocense explique diversos pasajes menianos como usos figurados:

Bruma... tómase por todo el invierno (8g).

Tridente... tómale aquí el poeta por la mar (11e).

Por el desierto entiende este mundo, en el cual hay religiosos y profanos (14eh).

Por el muro transparente entiende el elemento del aire (15c).

Sánchez evita aquí ilustrar sus anotaciones con referencias expresas a sinécdoque, metonimia, alegoría y metáfora, fundamentos de los anteriores lugares del Laberinto. Y ya el Comendador había glosado en esta manera, con la única excepción del tercer ejemplo («Allegoricós, por este desierto se ha de entender el mundo»).

No estamos ante un uso aislado dentro de Las obras del famoso poeta Juan de Mena, porque en las notas a la Coronación el Brocense procede de igual modo. Hemos examinado atrás un par de pasajes cuya base es la antonomasia - en torno a Séneca (12j) y Alpes (29c) - , pero la denominación del tropo no afloraba. Un caso análogo se halla en una alusión meniana que aúna metonimia y perífrasis, la designación de los preeminentes rayos solares como «la sobra / de la excelencia de Apolo» (45ij), que Sánchez se limita a parafrasear sin marbetes retóricos: "La sobra de Apolo es la gran luz y resplandor del Sol». 
No es fácil determinar por qué esta vaguedad denominativa. Es cierto que, por el destinatario de la obra, el tecnicismo estaba más justificado en el comentario de Alciato, pero, según acabamos de ver, otras ediciones del Brocense de carácter más escolar - las Silvas de Poliziano o los Bucolica de Virgilio-, aun de manera aislada, demuestran menores reticencias hacia la terminología retórica. El romance no parece impedimento, pues los conceptos y nombres grecolatinos, cuya raíz clásica no es óbice para el comentario de textos vernáculos, estaban habilitados desde la Gramática de Nebrija, el Arte poética de Encina y la Retórica de Miguel de Salinas. Sin duda, el modelo de Núñez, que en los susodichos pasajes del Laberinto tampoco era demasiado proclive al argot, condiciona al Brocense, que, frente al caso de las fuentes, apenas aprovecha para la precisión — salvo la síncopa de blasmar-, e incluso en algún caso aligera el detalle retórico del Comendador - el desierto como alegoría del mundo-.

Fuera de los metaplasmos y los tropos, Sánchez cataloga también como licencias ciertas inconsistencias en la materia fabulística del Laberinto, aparentes deslices de Mena que se juzgan admisibles como libertades de la creación poética. De este modo, en la copla 38 advierte Sánchez la confusión de las Tebas de Egipto y Beocia, «... y Juan de Mena parece que no advertió bien esto. Podríase defender que los poetas muchas vezes confunden las fábulas y toman un nombre por otro cuando son semejantes, como en lo de las dos Scyllas». La nota justificante deriva una vez más de Núñez, que ilustra el uso con pasajes de Lucano emanados de la toponimia homónima de Tebas. La referencia del Brocense a las dos Escilas - a saber, la ninfa Escila, futuro monstruo marino, y Escila de Megara, esta metamorfoseada en ave-, la empleaba ya el Comendador en contexto similar (Laberinto $217 \mathrm{~g}$ ), con ejemplos de mixtura de ambos personajes en Ovidio, Virgilio y Propercio. En general, en el comentario de estos procesos tolerables en cuanto licencias, el Brocense se acoge a la doctrina sancionada por el Comendador, según muestran estas otras dos anotaciones sanchianas: 
Los trabajos de Hércules son muy notorios, pero dos le atribuye aquí el poeta [el jabalí de Calidonia y las Arpías de Fineo] que no fueron suyos. Digamos que es licencia poética confundir las historias o fábulas (65ch).

El Catón mayor [el Censor] no se mató, sino murió de noventa años; mas nuestro poeta, como otros lo suelen hazer, atribuyó lo del uno [Catón de Útica] a entrambos (217eh).

Con respecto a Hércules, Núñez hacía gala de mayor finura al notar cómo, a propósito del mito de las Arpías en el banquete de Fineo, autores anteriores a Mena ya hacían protagonista del lance al semidiós. En cuanto a los Catones, el Comendador documentaba la misma confusión en Claudiano y Estacio, y otros casos análogos de homonimia cruzada con los Escévolas (Lucano), los Adastros (Propercio) y las antedichas Escilas. El fundamento de las glosas del Brocense, en cualquier caso, es idéntico.

Solo en una ocasión afín deja Sánchez de justificar poéticamente los versos del Laberinto: la anacrónica alusión a Euritión -el hermano de Pándaro vencedor del certamen de tiro en los juegos por Anquises en Sicilia (Aen. 5, 485-544) - como «aquel buen arquero de Roma» (88b): «Algunos descuidos hay en esta copla, porque Roma fue más de trezientos años después d'estos juegos». ${ }^{26}$ Frente a la mayoría de los ejemplos previos, esta mescolanza temporal no deriva de la homonimia, como tampoco los mitos pseudohercúleos tenían tal génesis. A Núñez no se le había escapado el detalle («No sé por qué dize el autor que Euryción fue de Roma...»), pero el Comendador mostraba mayor tino al cambiar el rumbo de su argumentación con

26 Tampoco Garcilaso se libra de alguna denuncia pareja, como la impropia distinción de los vientos Céfiro y Favonio en la Égloga III (v. 323), que el Brocense intenta justificar con una débil referencia: "Aquí sin duda se descuidó nuestro poeta, porque hace dos vientos siendo uno, porque al que los griegos llaman Zéphyro, porque 'trae la vida', llaman los latinos Favonio, porque 'favorece la vida', de modo que la cosa es una y los nombres son dos. Mas si alguno quisiere defender a Garci Lasso, sepa que Turnebo, varón doctísimo, en la segunda parte de sus Advertencias, cap. 32, dice que son diferentes vientos, y que lo dice Estrabón declarando un verso de Homero - yo no he hallado el lugar de Estrabón-» (Gallego Morell 1972: 302). 
una convincente correctio, que sin duda informa el proceso poético de Mena: «pero a aquello sin dubda tiende que de los troyanos vinieron los romanos». Aquí, pues, la síntesis del Brocense prescinde de un apunte esencial.

Horacio comenzaba precisamente su Ars poetica (vv. 1-23) tratando la audendi potestas de pintores y poetas, capaces de libertades tolerables dentro de unos márgenes, ridículas si rompen la simplicidad y unidad ideales de la obra. En su primer comentario horaciano, el Brocense interpretaba el alcance limitado de esta potestad creadora en dos niveles: deben respetarse el decoro y la coherencia en el asunto central, pero caben licencias en los detalles complementarios (De auctoribus interpretandis, «Primum praeceptum»; Mayans 1766, 2: 77-78; Merino 1992: 285287). Esta doctrina bien podría aplicarse a los anteriores pasajes del Laberinto, sobre elementos secundarios de materia entremezclada, pero el Brocense, pese a leerlos por lo general en clave de licencias poéticas, se abstiene de invocar a Horacio; y resulta extraño que desaproveche la ocasión de apuntalar una nota traída del Comendador mediante una referencia clásica procedente.

En líneas generales, la limitada anotación retórica y poética de los versos del Laberinto y la Coronación consuena dentro de la práctica comentarística del Brocense. Incluso en los Emblemata de Alciato, en donde aquellos elementos recibían una atención relativamente mayor, su tratamiento no alcanzaba un desarrollo relevante. Dada la orientación escolar de la mayoría de los comentarios de Sánchez, una de cuyas actividades docentes principales fue la oratoria, es necesario justificar estos cicateros silencios, máxime cuando la didáctica de la disciplina es preocupación central en sus escritos sobre retórica y poética (Merino 1992). En efecto, en la línea de Cicerón y Quintiliano, los humanistas fundaron el estudio de la retórica sobre natura, ars y exercitatio. Si la primera depende del ingenium y las condiciones innatas del individuo -en particular, de la memoria-, el ars requiere el estudio de los preceptos, que en la obra del Brocense cristalizan en dos manuales: el De arte dicendi (1556, con tres reediciones hasta 1573 ) y el Organum dialecticum et rhetoricum (1579 y 1588). Como 
tercera vía, la exercitatio consta de dos dimensiones conexas, el comentario de textos canónicos y la creación personal -esto es, enarratio e imitatio, correspondientes a analysis y genesis en la terminología de Ramus-. De ambos procesos, solo el comentario interesa al Brocense, según declara desde el título su De auctoribus interpretandis sive de exercitatione (1558): a su juicio, la imitatio, fundamental para el poeta, resulta prescindible para el filólogo, que se debe volcar en la enarratio. Y en concreto, según la doctrina de este opúsculo, los elementos susceptibles de análisis retórico son la inventio y la dispositio, no tanto la elocutio, el ámbito poético a que, en contraste, más atienden los principales comentarios del Brocense. En consecuencia, de acuerdo con Merino (1992: 174-175 y 278-281), esto implica que, en el propio marco teórico de Sánchez, sus ediciones anotadas no constituyen exercitationes oratorias en sentido estricto, si acaso exceptuadas las Sátiras de Persio por su paráfrasis, uno de los ejercicios canónicos del análisis retórico.

Por lo tanto, en una perspectiva escolar, de aquí se desprende que la mayoría de las ediciones del Brocense se conciben como materiales de apoyo sobre los que fundar el estudio gramatical y poético, cuya profundización se afrontaría en sus lecciones universitarias. En cuanto a la retórica, ello explica que los comentos se ocupen ante todo de la intelección del texto y, en consonancia, apenas incorporen notas oratorias y, cuando estas afloren, se ciñan al ornatus elocutivo, un elemento retórico secundario en la teoría comentarística del Brocense, pero el más provechoso a la hora de desvelar el sentido. ${ }^{27}$ La base de un texto inteligible asegura la eficacia pedagógica de las praelectiones y exercitationes subsiguientes, actividades propias de las aulas.

27 El Brocense no excluye, naturalmente, la elocutio del sistema retórico; es más, en contraste con De arte dicendi, la evolución teórica del Organum conduce a considerar la elocutio como la única dimensión propiamente oratoria, mientras que inventio y dipositio se encuadran más bien en la dialéctica (Merino 1992; Martín Jiménez 1997). Sin embargo, según estamos comprobando, en el modelo de análisis literario que propone De auctoribus interpretandis la elocutio es dimensión secundaria. 
Según hemos estado comprobando, el modelo de comentario de los poetas romances que cultiva el Brocense no difiere en lo esencial de su aproximación a los clásicos. Si esto es así, conviene evaluar el potencial uso de las obras de Mena y Garcilaso como textos universitarios: aunque no sería práctica ortodoxa, tenemos sobrada constancia documental acerca de las libertades docentes de Sánchez, que le comportarían numerosas advertencias y sanciones en el Colegio Trilingüe y la Universidad. ${ }^{28}$ En este sentido, ya Gallego Morell (1972: 20) reparó en la carta dirigida a Vázquez del Mármol a 17 de mayo de 1574 (Gallardo 1889, cols. 450-451), en donde el Brocense lamentaba el retraso de la impresión del Garcilaso, que inoportunamente vería la luz fuera del período lectivo, «porque son ya idos los más estudiantes, y todos holgaran de llevarlo consigo»: ya que trabaja con el alumno como lector ideal en mente, es lógico pensar que, más allá del buen negocio, las Anotaciones pudieran ser un útil didáctico.

Con esta perspectiva cobran nueva dimensión las dedicatorias del Garcilaso «divorciado» de 1569 (Salamanca, Matías Gast) o de la estampa anotada por el Brocense en 1589 (Salamanca, Diego López \& Pedro de Adurza), pues ambas, firmadas por los respectivos costeadores de la edición -los libreros Simón Borgoñón y Claudio Curlet-, se dirigen al rector salmantino Sancho Dávila y Toledo. Cierto es que este entroncaba por línea materna con la casa de Alba, y en ambos liminares el argumento central de la ofrenda radica en la circunstancia familiar y en que Garcilaso hubiese dedicado muchas de sus obras al ilustre linaje. Pero la propia dirección al rector auspicia un texto de pertinencia universitaria.

Y el caso de Mena es parejo, pues, por otras misivas del Brocense a Vázquez del Mármol, sabemos que, proyecto en curso, el nuevo comentario se concebía

28 Sigue siendo fundamental la documentación reunida y analizada por González de la Calle (1916 y 1922), en particular a propósito del conflicto sobre el uso conversacional obligatorio del latín en el Colegio Trilingüe y la actitud del Brocense, así como ciertas negligencias por dejación de funciones docentes. Tal independencia pedagógica, al invadir el campo de la teología, reportó a Sánchez graves problemas con la Inquisición (Bell 1925: 27-57). 
compañero del Garcilaso, "y que se puedan encuadernar juntos» (a 9 de septiembre de 1579; Gallardo 1889, cols. 452-453), de ahí el mismo formato de doceavo. ${ }^{29}$ De esta comunión emana el soneto de Alonso González de la Torre en los preliminares de la estampa meniana de 1582, que en realidad abarca ambos corpus poéticos, ligados por Sánchez «con desseo / de librar de las aguas del Letheo / al culto Lasso y docto Juan de Mena» (vv. 6-8), y los dos restituidos, un Garcilaso "ya del todo sepultado, / de la tiniebla obscura vuelto a vida» (vv. 10-11) y un Mena rescatado de su Laberinto, "por el ciego error perdido / que él mismo con su mano ha fabricado, / que apenas acertava la salida» (vv. 12-14).

No es prudente, sin embargo, derivar de aquí el inexorable uso de los comentarios de Mena y Garcilaso como textos universitarios, pues que el Brocense contemple a los estudiantes como sus principales lectores potenciales revela ante todo un interés comercial. En este sentido, según el examen de Bécares (2007: 29-52) en catálogos de librería salmantinos del s. XVI, al lado de los libros escolar y confesional hay otra importante veta constituida por el libro de lección, cuya finalidad es el entretenimiento, que tiene en la poesía romance una de sus concreciones. Con todo, también es verdad que las obras de Mena y Garcilaso se acompañan de las anotaciones del Brocense, y estas glosas, que allanan el proceso del leedor curioso, también forman al alumno de letras. Y es atendible que Sánchez escribiese para ambos círculos.

Alguna referencia a la literatura vernácula en el seno de los comentarios latinos del Brocense, por más que aislada, avala la hipótesis de su validez para ilustración de la doctrina poética. Por caso, según ha advertido Merino (1992: 277) a otro respecto, el Brocense recurre al referente ibérico del entremés a raíz del pasaje horaciano del Ars Poetica (vv. 220-250) sobre la combinación teatral de lo trágico y lo cómico: «Agit hic Horatius de episodiis, quos Hispani vocant entremeses, quod inter medio actus inserantur» (Mayans 1766, 2: 134). Y cuando detecta la alusión de Poliziano a estos

29 De este modo, el interesado podría encargar al librero la encuadernación conjunta de ambos trabajos; por lo tanto, no se trata en puridad de una edición conjunta de Mena y Garcilaso, como inadvertidamente se apunta en Casas (2016a: 442). 
versos en la silva Nutricia (v. 713), se vale de la misma referencia vernácula (Mayans 1766, 2: 496)..$^{30}$

En la actividad docente del Brocense, el análisis de poemas castellanos podía tener encaje dentro las clases de retórica. Sabemos que, frente a las prescripciones universitarias, que establecían la lectura de prosa oratoria de auctores como Cicerón, nuestro profesor se decantaba por la poesía, pese a las suspicacias de los colegas y visitadores salmantinos, si bien la documentación correspondiente apunta al abuso de poetas latinos. ${ }^{31}$ También es cierto que, en sus principales tratados retóricos, la ejemplificación del Brocense se circunscribe a los clásicos. Aunque extraña la escasez de referencias expresas a particularidades retóricas de la literatura romance, se ha intentado entresacar doctrina entre líneas. Así, respecto del numerus, Sánchez evoluciona desde el planteamiento clásico de Cicerón y Quintiliano hasta los nuevos postulados ramistas (Merino 1994b); y, pese a la ilustración exclusivamente latina, a juicio de Martín Jiménez (1997: 104-106), al considerar un ritmo natural propio de la musicalidad inherente al idioma frente a un ritmo artificial sustentado en la prosodia cuantitativa, el Brocense parece proyectar el concepto sobre el contraste de poesía vernácula y poesía clásica.

Desde aquí, la amplitud de miras de Sánchez y su indisciplina pedagógica hacen verosímil el uso subrepticio de Mena y Garcilaso en las clases de retórica. Como analogía gramatical, es notorio su afán innovador en la enseñanza del latín, pues, con el ilustre precedente de Vives, Sánchez fue pionero en la defensa del romance como

30 Horacio se refiere a la delicada conjunción de elementos serios y jocosos en el seno del drama satírico, modalidad a medio camino entre la tragedia y la comedia, que el Brocense interpreta forzadamente como representación de una pieza cómica en el entreacto de otra obra teatral.

31 Así, en las denuncias cruzadas en 1564 entre el Brocense y León de Castro, este proclama ceñirse a la prosa Cicerón como lectura obligatoria, y no a los poetas, con lo cual acusa a Sánchez de incurrir en una práctica vedada: «... porque yo no examino en poetas y libros oscuros, sino en unas epístolas de Tulio...» (González de la Calle 1916: 297). Antes y después, recriminaciones análogas precisaban ciertas preferencias poéticas de Sánchez, como Marcial y Juvenal, lecturas estatutariamente improcedentes en las clases de retórica (González de la Calle 1922: 68-72, 87). 
lengua docente y discente, en contra de los estatutos universitarios. La segunda de sus Paradoxa, incorporada como coda a la Minerva de 1587, aboga por esta alternativa didáctica, en particular justificable con escolares primerizos. De tal principio deriva la edición conjunta de las Verae brevesque grammatices Latinae institutiones con su compendio romanceado, el Arte para en breve saber latín (1595). Por este camino, el uso de textos romances en las primeras prácticas del análisis retórico sería la correlación esperable. De hecho, el acento del Brocense sobre la imitatio, así en el prólogo como en las propias anotaciones a Garcilaso, sitúan este comentario en un lugar de privilegio para ilustrar un concepto poético esencial, que Sánchez aprecia desde la ladera del comentarista antes que el creador. Por añadidura, en el Garcilaso la cita abundante de poetas antiguos (Virgilio, Horacio y Ovidio) y algún coetáneo como Girolamo Fracastoro habilita las anotaciones como antología latina susceptible de análisis retórico. Los escolios sobre el proceso imitativo no son desdeñables en el comento del Laberinto, por más que el abrumador catálogo de fuentes anticipado por Núñez limite al Brocense, de ahí que la proporción de citas decrezca a la par, aun siendo destacable - ahí están los mismos Virgilio, Horacio y Ovidio, o incluso Cicerón-. De otra parte, en el dominio elocutivo, las notas de Sánchez a Mena trazan las líneas maestras de los metaplasmos y licencias de los poetas.

Ante tal panorama, lo verdaderamente extraordinario sería que el Brocense no se hubiese servido de sus ediciones de Mena y Garcilaso en sus clases sobre retórica, siquiera como introducción y complemento del análisis de los clásicos.

\section{CONCLUSIONES}

Las obras del famoso poeta Juan de Mena brindan al lector de fines del Quinientos un corpus remozado de acuerdo con el método filológico del Brocense. Según el plan inicial, Sánchez preparó una edición anotada del Laberinto y la Coronación, de filia grecolatina; en otro momento, a sugerencia de Juan Vázquez 
del Mármol y seguramente inducido por los intereses comerciales del impresor y plausible costeador, Lucas de Junta, el Brocense asume de buen grado la ampliación del volumen; y si bien apenas anota los demás poemas, no renuncia a pulir sus textos.

Para ponderar el trabajo meniano del Brocense no basta su cotejo con la edición de Garcilaso, pues los textos clásicos y neolatinos anotados por Sánchez contribuyen a perfilarlo mejor. A grandes rasgos, sus ediciones comentadas comparten una base común, pero el grado de dificultad de la obra, su transmisión textual y el destinatario imponen condicionantes decisivos.

Como principio ecdótico, cada edición del Brocense parte de una vulgata, estampa reciente que proporciona un texto base que limar mediante enmiendas. Seguía siendo lo usual fuera de Italia, pese a que Sánchez conocía cuando menos la Miscellanea de Poliziano, cuyo método genealógico desarrollaban entonces Piero Vettori o Antonio Agustín. Por lo que hace al Laberinto, el Brocense sigue la segunda versión del texto de Hernán Núñez, aparecida en 1505; y si bien es difícil determinar cuál de las sucesivas estampas hasta 1566 fue su referente principal, sin duda manejó varias. Desde 1506, las ediciones del Laberinto glosado por Núñez sumarían progresivamente otros poemas de Mena, proceso que culmina en los trabajos amberinos de Nucio y Steelsio de 1552, a cuyo corpus la colección del Brocense solo añade dos adivinanzas de paternidad dudosa. Es probable que Sánchez emplease una de estas antologías u otra afín como base; en particular, "El Sol clarecía los montes acayos» y "Ya el hijo muy claro de Hiperión» comparten equipolencias y errores con el impreso de Steelsio, lo cual es indicio antes que prueba decisiva, pues no todas las composiciones del volumen tendrían por qué basarse en la misma estampa.

En cuanto al tipo de comentario, el Brocense adopta el modelo de anotación selectiva, ceñida a los elementos de la obra que el comentarista considera más reseñables, según la alternativa imperante desde finales del s. XV. El principio del texto base se extiende a los comentarios previos, que desde antiguo se aprovechan sin declaración, salvo para contradecirlos; en esta línea, el Brocense despoja al propio 
Mena en la Coronación y en el Laberinto al Comendador, a quien cita principalmente para su corrección. En este caso, el resultado es un Núñez extractado y puesto al día, gracias a lo cual el Laberinto podrá ser leído «con más claridad y menos pesadumbre».

Para la exercitatio o análisis retórico, Sánchez teoriza sobre el examen de la quaestio central de la obra, los argumenta y su dispositio, tríada que se puede complementar con unas anotaciones explanatorias. Pero en la práctica, sus comentarios normalmente se circunscriben a estas annotationes, dirigidas a un público escolar o un lector análogo, no tanto al erudito. Hay, con todo, diversos grados de exigencia, porque el comentario de Alciato mantiene una estructura recurrente que intenta cubrir los intereses de estudiante y estudioso. El destinatario habitual, sin embargo, será más bien el lector bisoño, para quien se allana la intelección donde resulta imprescindible, de ahí el relativo asistematismo de las notas. Este modelo, representado por la primera edición comentada del Brocense - las Silvas de Poliziano-, caracteriza asimismo su anotación de Mena.

Que el legatario ideal del comento sea el estudiante no implica que toda edición del Brocense esté estrictamente concebida como libro de estudio universitario. En este dominio, las obras de Mena y Garcilaso se encuentran en una encrucijada: de una parte, consta que Sánchez tenía en mente al lector estudiantil para su Garcilaso, y que el Mena se imprimiría con igual formato para que ambos trabajos pudiesen encuadernarse juntos; de otra, los estatutos universitarios fijaban el estudio de los prosistas latinos en las clases de retórica. Con todo, Sánchez, el mismo profesor que, contra la normativa salmantina, abogaba por la enseñanza del latín en castellano, plausiblemente haría uso de textos romances en sus lecciones de oratoria, cuando menos con alumnos primerizos.

Las anotaciones del Brocense se ocupan sobre todo de la exégesis en sentido estricto, con menor atención a la crítica textual y un escaso análisis poético. El nexo de estos tres estratos son las fuentes del poeta, que determinan el sentido de la obra, el texto y el estilo. 
La exégesis reclama atención a los planos verbal y conceptual del escrito. Aquí la cronología, el registro y la lengua condicionan las necesidades de cada comento. De este modo, los clásicos requieren mayor desbroce lingüístico y de realia que los modernos, en especial los vernáculos. Por ello, es natural que el Ibis y el Gryphus, tan oscuros, exijan más explanación de léxico y gramática que los Emblemata de Alciato; o que el Laberinto, poema cultista compuesto siglo y medio atrás, solicite escolios de este carácter antes que los versos de Garcilaso, de estilo medio y cuasi coetáneos. Por ello, de estos procesos y ajustes filológicos no cabe derivar evaluaciones estéticas diversas del Brocense.

Similar prevención conviene a propósito de las fuentes, caballo de batalla de los comentarios de Sánchez. Desde 1577, el prólogo del Garcilaso justifica el rastreo de modelos como reivindicación del principio de imitatio; en particular, el Brocense tiende a señalar la conciliación de fuentes varias bajo los versos garcilasianos, mientras que, para Mena, el auctor apuntado suele ser único. Pero esto último, en el fondo, es un antídoto contra Núñez, que había abrumado al lector con infinidad de referencias intertextuales, un maremágnum que no siempre discriminaba la fuente estricta del vago paralelismo: la poda que ejecuta Sánchez proclama precisión, por lo que, frente al acarreo, se impone lacónica la remisión al modelo pertinente. En consecuencia, de aquí no se desprenden necesariamente distintos itinerarios imitativos en Mena y Garcilaso; lo que varía es el método anotador.

El escolio retórico y poético escasea en la producción sanchiana, según una línea que privilegia la exégesis declaradora. Dentro de esta convención se entienden las chanzas a costa de Herrera, para el Brocense improcedentemente afanado en el estilo de Garcilaso. Si acaso, sus Emblemata alciatinos, destinados al lector europeo, reciben una moderada atención métrica y elocutiva, aunque irregular. El tratamiento de estos elementos en las obras de Mena responde al constrictivo patrón dominante en el Brocense, al servicio de la intelección; y esto pese a que el prólogo ponderaba el estilo del Laberinto por su adecuación al género heroico, una crisis sin correspondencia 
en las magras anotaciones de poética, limitadas incluso en el uso del metalenguaje teórico. Y si, de modo similar, tampoco pesa la anotación estilística de Virgilio, Ovidio, Persio o Poliziano, es claro que el profesor de retórica emplearía esta clase de ediciones como lecturas susceptibles de un tipo de análisis poético que, sobre aquellos textos, se afrontaba después en las aulas. ${ }^{32}$

32 Como complemento y colofón de este trabajo, en un próximo "Las obras del famoso poeta Juan de Mena en el contexto filológico del Brocense: las notas de crítica textual» se revisará la vertiente ecdótica del comentario. 


\section{BIBLIOGRAFÍA CITADA}

ASENSIO, Eugenio (1981), "El ramismo y la crítica textual en el círculo de Luis de León. Carteo del Brocense y Juan de Grial», en Fray Luis de León. Actas de la I Academia Literaria Renacentista, ed. Víctor García de la Concha, Salamanca, Universidad, pp. 47-76.

ASENSIO, Eugenio (1984), «El Brocense contra Fernando de Herrera y sus Anotaciones de Garcilaso", El Crotalón, 1, pp. 13-24.

BÉCARES BOTAS, Vicente (2007), Librerías salmantinas del siglo XVI, Segovia-Burgos, Caja Segovia - Fundación Instituto Castellano y Leonés de la Lengua.

BeLL, Aubrey F. (1925), Francisco Sánchez el Brocense, Oxford, University Press.

Brocato, Linde M. (2012), "Publishing Juan de Mena: An Overview of the Editorial Traditions», Revista de Cancioneros Impresos y Manuscritos, 1, pp. 1-40. https://doi.org/10.14198/rcim.2012.1.01

CASAS RigALL, Juan (2106a), «El accessus a Juan de Mena en tres comentaristas del Laberinto de Fortuna (anónimo del Cancionero de Barrantes, Hernán Núñez y el Brocense)», Bulletin Hispanique, 118, pp. 431-451. https://doi.org/10.4000/ bulletinhispanique. 4473

CASAS RIGALL, Juan (ed.) (2016b), Juan de Mena y el "Laberinto» comentado: tempranas glosas manuscritas (c. 1444-1479). Estudio, edición crítica y notas, Salamanca, Universidad («Textos Recuperados», 32). https://doi.org/10.2307/j.ctt1z27gvj

CASAS RigalL, Juan (2020), "Hernán Núñez ante el texto del Laberinto: elementos de ecdótica antigua y humanística», Revista de Poética Medieval, 34, pp. 25-61. https://doi.org/10.37536/RPM.2020.34.0.77990

CODOÑER, Carmen (1986), "Comentaristas de Garcilaso», en Garcilaso. Actas de la IV Academia Literaria Renacentista, ed. Víctor García de la Concha, Salamanca, Universidad, pp. 185-200.

CODOÑER, Carmen (1988), "Ratio en el Brocense», en Stephanion. Homenaje a María C. Giner, ed. Carmen Codoñer et al., Salamanca, Universidad, pp. 177-182.

COROLEU, Alejandro (2014), Printing and Reading Italian Latin Humanism in Renaissance Europe (ca. 1470-ca. 1540), Newcastle, Cambridge Scholars Publising.

DAZA, Bernardino (1549), Los emblemas de Alciato traducidos en rimas españolas, Lyon, Rouillé; ed. Rafael Zafra, Barcelona, Olañeta - Universitat de les Illes Balears, 2003.

De Nigris, Carla (ed.) (1988), Juan de Mena, Poesie minori, Nápoles, Liguori. 
Fortuny PreVI, Filomena (1989), «El Brocense y la sátira I de Persio», Estudios Románicos, 4, pp. 403-412.

Foulché-DelBosc, Raymond (ed.) (1904), Juan de Mena, Laberinto de Fortuna, Protat, Mâcon.

GALLARDO, Bartolomé José (1889), Ensayo de una biblioteca española de libros raros y curiosos, formados con los apuntamientos de..., coordinados y aumentados por D. R. Zarco del Valle y D. J. Sancho Rayón. Tomo cuarto, Madrid, Tello [reimpresión, Madrid, Gredos, 1968].

Gallego Morell, Antonio (ed.) (1972²), Garcilaso de la Vega y sus comentaristas, Madrid, Gredos [1aㅡ ed.: Granada, Universidad, 1966].

Gómez Moreno, Ángel, \& Teresa Jiménez CALVente (eds.) (1994), Juan de Mena, Obra completa, Madrid, Turner («Biblioteca Castro»).

González dE LA CALLE, Pedro Urbano (1916), «Latín y romance. Contribución al estudio de la vida docente española en el siglo XVI», en Varia. Notas y apuntes sobre temas de letras clásicas, Madrid, Victoriano Suárez, pp. 211-299.

González de LA CALLE, Pedro Urbano (1922), Vida profesional y académica de Francisco Sánchez de las Brozas: ensayo biográfico, Madrid, Victoriano Suárez.

GRAFTON, Anthony (1983), Joseph Scaliger. A Study in the History of Classical Scholarship.

I. Textual Criticism and Exegesis, Oxford, Clarendon Press.

GuARINo ORTEGA, Rosario (1996), "El Brocense, comentarista del Ibis de Ovidio», en La recepción de las artes clásicas en el siglo XVI, ed. Eustaquio Sánchez Salor et al., Cáceres, Universidad de Extremadura, pp. 651-656.

HINOJO, Gregorio (2003), "Los comentarios del Brocense a los autores clásicos», en El Brocense y las humanidades en el siglo XVI, ed. Carmen Codoñer et al., Salamanca, Universidad, pp. 329-345.

Jiménez CALVEnTE, Teresa (2002), "Los comentarios a las Trescientas de Juan de Mena», Revista de Filología Española, 82/1-2, pp. 21-44. https://doi.org/10.3989/ rfe.2002.v82.i1/2.142

Kenney, Edwin J. (1974), The Classical Text. Aspects of Editing in the Age of the Printed Book, Berkeley-Los Ángeles-Londres, University of California Press.

KerkHof, Maximiliam P. A. M. (ed.) (1995), Juan de Mena, Laberinto de Fortuna, Madrid, Castalia («Nueva Biblioteca de Erudición y Crítica», 9).

KerkHof, Maximiliam P. A. M. (ed.) (2009), Juan de Mena, La Coronación, Madrid, CSIC. 
KoнUт, Karl (1975), «Der Kommentar zu literarischen Texten als Quelle der Literaturtheorie im spanischen Humanismus. Die Kommentare zu Juan de Mena und Garcilaso de la Vega», en Der Kommentar in der Rennaisance, ed. August Buck y Otto Herding, Bonn, Deutsche Forschungsgemeinschaft, pp. 191-208.

KULCSÁR, Péter (ed.) (1987), Mythographi Vaticani l et II, Turnholt, Brepols («Corpus Christianorum S. L.", 91C).

LIDA De Malkiel, Mạ Rosa (1950), Juan de Mena, poeta del Prerrenacimiento español, México D. F., El Colegio de México.

LóPEZ-CAÑETE QUILES, Daniel (1999), "Aristóteles y la teoría del análisis literario en el Brocense (De avctoribus interpretandis sive de exercitatione praecepta)", Habis, 30, pp. 377-389.

MAÑAS NúÑEZ, Manuel (1993), "La crítica textual en las Annotationes in Griphum Ausonii del Brocense», Anuario de Estudios Filológicos, 16, pp. 235-246.

MAÑAS VINIEGRA, Francisco Javier (1992), «Aproximación al estudio de las Adnotationes in Bucolica Virgilii del Brocense», Alcántara. Revista del Seminario de Estudios Cacereños, 27, pp. 7-24.

MAÑAS VINIEgRA, Francisco Javier (1993), «El Brocense, comentarista de Virgilio: análisis exegético de la égloga IV», Anuario de Estudios Filológicos, 16, pp. 247262.

MAÑAS VINIEgRA, Francisco Javier (ed.) (2014), Las «Adnotationes» del Brocense a los Bucolica de Virgilio, Calamonte, Filarias.

MARTín ABAD, Julián (1991), La imprenta en Alcalá de Henares (1502-1600), Madrid, Arco Libros, 3 vols.

MARTín JimÉnEZ, Alfonso (1997), Retórica y literatura en el siglo XVI. El Brocense, Valladolid, Universidad.

MAYANS Y SISCAR, Gregorio (ed.) (1766), Francisci Sanctii Brocensis ... Opera omnia, una cum eiusdem scriptoris vita, Ginebra, Fratres de Tournes, 4 vols. [reimpresión, Hildesheim-Zürich-New York, Georg Olms, 2 vols.].

MERINO JEREZ, Luis (1992), La pedagogía en la retórica del Brocense, Cáceres, Institución Cultural «El Brocense» - Universidad de Extremadura.

MERINO JEREZ, Luis (1994a), "Aproximación al De auctoribus interpretandis y a los In Artem Poeticam annotationes del Brocense», en Humanismo y pervivencia del mundo clásico I, 2, ed. José Mạ Maestre y Joaquín Pascual, Cádiz, Universidad, pp. 621-631. 
Merino Jerez, Luis (1994b), "Numerus en la Rhetorica del Brocense», en Humanismo y pervivencia del mundo clásico I, 2, ed. José Ma Maestre y Joaquín Pascual, Cádiz, Universidad, pp. 633-642.

Merino Jerez, Luis (1996), "Las Silvas de Poliziano comentadas por el Brocense», Humanistica Lovaniensia, 45, pp. 406-429.

Merino Jerez, Luis (2004), "Los Emblemas de Alciato comentados por El Brocense (1573) y glosados por Mal Lara (1568)», en Florilegio de estudios de Emblemática = A Florilegium of Studies on Emblematics. Actas del VI Congreso Internacional de Emblemática de The Society for Emblem Studies = Proceedings of the 6th International Conference of The Society for Emblem Studies, ed. Sagrario López Poza, La Coruña, Sociedad de Cultura Valle-Inclán, pp. 521-530.

Merino Jerez, Luis, \& Jesús Ureña BraCero (2004), «On the Date of Composition of El Brocense's Commentaria in Alciatii Emblemata», Emblematica, 13, pp. 73-96.

Morros, Bienvenido (2003), «El Brocense en los textos de Juan de Mena y de Garcilaso de la Vega», en El Brocense y las humanidades en el siglo XVI, ed. Carmen Codoñer et al., Salamanca, Universidad, pp. 347-371.

NúÑEZ DE TOLEDo, Hernán (ed.) (1499), Glosa sobre las Trezientas del famosíssimo poeta Juan de Mena, Sevilla, Juan Pegnitzer - Magno Herbst - Tomás Glockner.

Oroz RetA, José, \& Manuel Marcos CASquero (eds.) (1982-1983), Isidoro de Sevilla, Etimologías, Madrid, BAC, 2 vols.

PACKARD HuMANITIES INSTITUTE (2021), PHI. Classical Latin Texts. https://latin.packhum. org/index [consulta: 11/08/2021].

PePE, Inoria, \& José María Reyes (eds.) (2001), Fernando de Herrera, Anotaciones a la poesía de Garcilaso, Madrid, Cátedra.

PÉrez Priego, Miguel Ángel (ed.) (1979), Juan de Mena, Obra lírica, Madrid, Alhambra. Rosso Gallo, María (ed.) (1990), La poesía de Garcilaso de la Vega. Análisis filológico y texto crítico, Madrid, CSIC.

Ruiz FidAlgo, Lorenzo (1994), La imprenta en Salamanca (1501-1600), Madrid, Arco Libros, 3 vols.

RUIz PÉREZ, Pedro (1988), "Las Anotaciones del Brocense. Retórica e ideas poéticas renacentistas", Rilce, 4/2, pp. 73-98.

SÁNCHEZ DE LAS BROZAS, Francisco $\left(1577^{2}\right)$, Las obras del excelente poeta Garci Lasso de la Vega, Salamanca, Pedro Lasso [1a ed.: Salamanca, Pedro Lasso, 1574]. 
SÁNCHEZ de LAS BRozAS, Francisco (1582), Las obras del famoso poeta Juan de Mena, Salamanca, Lucas de Junta.

SÁNCHEZ DE LAS BROZAS, Francisco (15894), Las obras del excelente poeta Garci Lasso de la Vega, Salamanca, Diego López y Pedro de Adurza para Claudio Curlet [1aㅡ ed.: Salamanca, Pedro Lasso, 1574].

SÁNCHEZ DE LIMA, Miguel (1580), El arte poética en romance castellano, Alcalá, íñiguez de Lequerica.

SÁnCHEZ SAlor, Eustaquio, \& César ChapARro Gómez (eds.) (1995), Francisco Sánchez de las Brozas, Minerva seu de causis linguae, Cáceres, Institución Cultural «EI Brocense».

SELIG, Karl-Ludwig $\left(2018^{2}\right)$, Studies on Alciato in Spain, ed. Peter Jehle et al., Kassel, Reichenberger [1a ed.: New York, Garland, 1990].

SıMón DíAz, José (1965), Bibliografía de la literatura hispánica. Tomo III, Madrid, Instituto "Miguel de Cervantes» de Filología Hispánica, 2 vols.

TALAVERA ESTESO, Francisco José (1996), «Los comentarios humanísticos españoles a los Emblemas de Alciato en el siglo XVI», en La recepción de las artes clásicas en el siglo XVI, ed. Eustaquio Sánchez Salor et al., Cáceres, Universidad de Extremadura, pp. 679-686.

Ureña Bracero, Jesús (2004), "Tipología de los comentarios del Brocense a los Emblemas de Alciato", en Florilegio de estudios de Emblemática = A Florilegium of Studies on Emblematics. Actas del VI Congreso Internacional de Emblemática de The Society for Emblem Studies = Proceedings of the 6th International Conference of The Society for Emblem Studies, ed. Sagrario López Poza, La Coruña, Sociedad de Cultura Valle-Inclán, pp. 653-660.

VASVARI, Louise O. (ed.) (1976), Juan de Mena, Laberinto de Fortuna, Madrid, Alhambra. WEISS, Julian, \& Antonio CORTIJO OCAÑA (eds.) (2015), Hernán Núñez de Toledo, Glosa sobre las Trezientas del famoso poeta Juan de Mena, Madrid, Polifemo. 